\title{
BISKUPI KATOWICCY O ŚWIĘTOWANIU NIEDZIELI PODCZAS PIELGRZYMEK STANOWYCH DO PIEKAR ŚLĄSKICH PO II WOJNIE ŚWIATOWEJ
}

\section{Wprowadzenie}

Niedziela, często określana jako dzień Pański, ma ogromne znaczenie dla życia chrześcijańskiego, gdyż stanowi centrum życia liturgicznego. Dzień ten określa się mianem „małej Wielkanocy”, ponieważ jest pamiątką zmartwychwstania Jezusa. Chrześcijanin zatem jest zobowiązany do przestrzegania świątecznego charakteru tego dnia poprzez wypełnienie Tradycji apostolskiej oraz trzeciego przykazania Dekalogu ${ }^{1}$.

Centrum niedzieli dla każdego chrześcijanina stanowi Eucharystia, którą uważa się za „serce Kościoła”. Wagi nabiera więc udział w niedzielnej Mszy Świętej będącej wspomnieniem męki, śmierci i zmartwychwstania Chrystusa. Jak głosi Konstytucja o liturgii świętej Soboru Watykańskiego II: „niedziela jest zatem pierwotnym dniem świątecznym, który należy tak przedstawiać wiernym i wpajać w ich pobożność, aby stał się również dniem radości i odpoczynku od pracy"2.

1 Sobór Watykański II, Konstytucja o liturgii świętej „,Sacrosanctum Concilium”, nr 106, w: Sobór Watykański II. Konstytucje, dekrety, deklaracje. Tekst łacińsko-polski, wyd. 2, Poznań 2008, s. 93, 95; Katechizm Kościoła Katolickiego, wyd. 2, Poznań 2002 [dalej: KKK], nr. 1166-1167, 1343, 2174-2176, 2698; Kodeks prawa kanonicznego, Poznań 1984 [dalej: KPK], kan. 1246, § 1; H. Olszar, „Niedziela Boża i nasza”. Walka biskupa Herberta Bednorza z władza ludowa o Dzień Pański wolny od pracy, w: Świętowanie niedzieli w wymiarze społeczno-etycznym. XXII Społeczne Sympozjum Piekarskie, red. A. Wuwer, Katowice 2013, s. 36-37; A. Hoinkis, Teologia świętowania niedzieli jako dnia Pańskiego, w: Świętowanie niedzieli..., dz. cyt., s. 169-178; A. Wuwer, D. Szlachta, Caritas et Iustitia in re sociali. Przesłanie społeczne biskupów katowickich podczas stanowych pielgrzymek mężczyzn do Piekar Śląskich (1966-2010). Edycja źródeł z komentarzem, Katowice 2017, s. 305; A. Wuwer, D. Szlachta, Mater et Familiae Advocata. Przesłanie społeczne biskupów katowickich podczas stanowych pielgrzymek kobiet i panien do Piekar Śląskich (1966-2016). Edycja źródeł z komentarzem, Katowice 2017, s. 175.

2 Cyt. za Konstytucja o liturgii świętej „,Sacrosanctum Concilium”, w: Sobór Watykański II. Konstytucje - Dekrety - Deklaracje, wyd. 2, Poznań 2008, s. 95. Temat niedzieli jako centrum życia chrześcijańskiego pojawia się także na pielgrzymkach stanowych. Jako przykład można przywołać pielgrzymkę kobiet w 2003 r. Podczas niej abp Damian Zimoń mówił: „tak ważne jest świadome, pobożne i owocne uczestniczenie we Mszy Świętej. Wielu uczestników niedzielnej Mszy Świętej to obcy i niemi widzowie. Wzrasta liczba tych, którzy w ogóle nie uczestniczą w Eucharystii. To powinno się zmienić”, za: A. Wuwer, D. Szlachta, Mater et Familiae Advocata..., dz. cyt., s. 185. 
Uczniowie Chrystusa gromadzą się na Eucharystii, obchodząc pamiątkę wydarzeń z Wieczernika oraz Golgoty poprzez karmienie się Jego słowem i Ciałem. Uczestnictwo w niedzielnej liturgii może też być świadectwem przynależności do Kościoła ${ }^{3}$.

Ważną rolę w świętowaniu niedzieli odgrywa powstrzymanie się od prac niekoniecznych wszelkiego rodzaju. Trafnie oddaje to wykładnia nowego brzmienia przykazań kościelnych, która stanowi, że „chodzi o prace utrudniające lub uniemożliwiające: oddawanie Bogu czci, przeżywanie radości właściwej dniowi świątecznemu, korzystanie z należytego odpoczynku duchowego i fizycznego"4. Niedziela zatem nabiera znaczenia jako „dzień człowieka”, ponieważ umożliwia odpoczynek po pracy oraz nawiązanie więzi rodzinnych i społecznych ${ }^{5}$.

Wątek świętowania niedzieli pojawia się także w przemówieniach biskupów katowickich wygłaszanych podczas pielgrzymek stanowych do sanktuarium Matki Bożej Piekarskiej, czyli pielgrzymek mężczyzn i młodzieńców w ostatnią niedzielę maja oraz pielgrzymek kobiet organizowanych w niedzielę po 15 sierpnia. Początki pielgrzymek stanowych w dzisiejszej formie sięgają zakończenia II wojny światowej. Wówczas pojawiła się idea zorganizowania pielgrzymki mężczyzn i młodzieńców, która po raz pierwszy odbyła się w maju 1947 r. Do jej inicjatorów należał późniejszy biskup katowicki, Herbert Bednorz. Od 1946 r. pełnił on obowiązki referenta duszpasterskiego, później jako czwarty biskup katowicki doprowadził do ich rozwoju ${ }^{6}$.

W okresie jego posługi jako ordynariusza diecezji katowickiej pielgrzymki piekarskie mocno się zrosły z głoszeniem nauki społecznej Kościoła. Okazało się to nadzwyczaj potrzebne, ponieważ robotnicy byli pozbawieni możliwości walki o swoje prawa. Działające wówczas związki zawodowe prowadziły działalność ideologiczną, wielu zaś ich członków należało do PZPR. W rezultacie jedyną instytu-

3 KKK 1389; Liturgia święta, w: Wiara, modlitwa i życie w Kościele katowickim, red. B. Woźnica, I. Mierzwa, M. Połomska, R. Rak, S. Szymecki, wyd. 2, Katowice 2012, s. 84; M. Basiuk, Biblijne i patrystyczne korzenie świętowania dnia Pańskiego, w: Świętowanie niedzieli..., dz. cyt., s. 135-142.

4 Cyt. za: Pięć przykazań kościelnych, „Wiadomości Archidiecezjalne. Organ Urzędowy Archidiecezji Katowickiej” [dalej: WA] 82 (2014), nr 4, s. 141.

5 KPK, kan. 1247; KKK 2042; Pięć przykazań kościelnych..., art. cyt., s. 141; W. Surmiak, ,, W niedzielę oraz święta nakazane uczestniczyć we mszy świętej i powstrzymać się od prac niekoniecznych" - prawno-moralny sens pierwszego przykazania kościelnego, w: Świętowanie niedzieli..., dz. cyt., s. 143-159; P. Til, Biskupi polscy o świętowaniu niedzieli, Katowice 2017, s. 120, 193.

6 O początku pielgrzymek stanowych oraz ich przebiegu: zob. J. Górecki, Pielgrzymki do Piekar Ślaskich w latach 1946-1947 w świetle okólników Kurii Diecezjalnej w Katowicach, „Peregrinus Cracoviensis” 26 (2015), nr 1, s. 21-34; A. Wuwer, D. Szlachta, Caritas et Iustitia in re sociali..., dz. cyt., s. 46-55; D. Szlachta, Pielgrzymki stanowe do sanktuarium w Piekarach Śląkich w latach 1945-2020, „Studia Sandomierskie” 27 (2020), s. 139-169. Pielgrzymki kobiet rozpoczęły się nieco wcześniej, bo w 1933 r. 
cją wspierającą świat pracy na Górnym Śląsku był miejscowy Kościół. Jak określił to abp Wiktor Skworc, kapelan bp. Bednorza w latach 1975-1980: Kościół jest „głosem nie mających głosu”. Jednym z wydarzeń odgrywających ważną rolę w tej walce zawsze były piekarskie pielgrzymki stanowe, które przyczyniły się do czci obrazu Matki Bożej Piekarskiej pod tytułem „Matki Sprawiedliwości i Miłości Społecznej"7.

Jednym z najważniejszych punktów pielgrzymki stanowej w Piekarach Śląskich jest słowo biskupa katowickiego, w którym podejmuje on aktualne problemy społeczne. Do najważniejszych tematów poruszanych podczas przemówień należy również zagadnienie świętowania niedzieli. Można to zauważyć zarówno w okresie PRL, jak i po przemianach 1989 r. Tradycja ta ma swoją kontynuację także dzisiaj, kiedy niedziela jest zagrożona z powodu nacisku na zysk i otwarcia centrów handlowych w dni świąteczne. Jak się okazuje, dochodzi do tego mimo oficjalnego wejścia w życie ustawy o zakazie handlu niedzielnego ${ }^{8}$. Toteż niezależnie od sytuacji biskupi katowiccy ukazują niedzielę jako „dzień Boga i człowieka”"

\section{Walka o niedzielę w czasach PRL}

Zagadnienia związane ze świętowaniem niedzieli były jednym z najważniejszych tematów poruszanych podczas pielgrzymek stanowych do Piekar Śląskich. Daje się to zauważyć przede wszystkim w przesłaniach wygłaszanych przez bp. Herberta Bednorza, ordynariusza diecezji katowickiej w latach 1967-1985. Za swoich rządów

7 Rozmowa z abp. Wiktorem Skworcem z 3 kwietnia 2014 r. przeprowadzona przez D. Szlachtę (w zbiorach autora); G. Olszowski, Herbert Bednorz-organizator i kierownik referatu duszpasterskiego Kurii Diecezjalnej w Katowicach, w: Biskup Herbert Bednorz - zycie i postuga czwartego biskupa katowickiego. W setna rocznice urodzin biskupa Herberta Bednorza (1908-2008), red. I. Celary, Katowice-Piekary Śląskie 2008, s. 87-88, 92-93; A. Wuwer, Etyczno-społeczna interpretacja maryjnego tytułu „,Matka sprawiedliwości i miłości społecznej”, w: Sprawiedliwość i miłość społeczna. Refleksja interdyscyplinarna w 90-lecie (archi)diecezji katowickiej, red. A. Wuwer, Katowice 2015, s. 15-17; D. Szlachta, Tematy społeczne poruszane przez biskupów katowickich podczas pielgrzymek stanowych do Piekar Śląskich, w: Wolność człowieka i jej granice, red. K. Kozioł, Lublin 2017, s. 72-73; D. Szlachta, Herbert Bednorz (1908-1989), , biskup robotników”, w: Logos $i$ ethos $w$ polityce. Księga jubileuszowa Profesora Stanisława Wójcika, red. A. Łukasik-Turecka, K. Słowiński, Lublin 2020, s. 77-97; D. Szlachta, Bednorz Herbert, w: Leksykon Panteonu Górnoślaskiego, red. A. Kłos-Skrzypczak, H. Olszar, Katowice 2020, s. 53-61.

8 Zob. W. Skworc, Ojcowskim sercem. Stowo społeczne Metropolity Katowickiego, WA 89 (2021), nr 5, s. 348-349.

9 Rozmowa z abp. Wiktorem Skworcem z 3 kwietnia 2014...; W. Skworc, Idźcie i głoście! Jest nadzieja! Słowo Arcybiskupa Katowickiego podczas pielgrzymki stanowej mężczyzn i młodzieńców do Sanktuarium Matki Bożej Piekarskiej 28 maja 2017 roku, WA 85 (2017), nr 5, s. 335; R. Misiak, Świętowanie dnia Pańskiego w perspektywie tożsamości, w: Świętowanie niedzieli..., dz. cyt., s. 101-107; P. Til, Biskupi polscy..., dz. cyt., s. 184-185. 
bp Bednorz przyczynił się do rozwoju duszpasterstwa świata pracy i z tego powodu zyskał przydomek „biskupa robotników”10.

Zagadnienie świętowania niedzieli w przemówieniach biskupa katowickiego pojawiało się w kontekście zachowania sakralnego charakteru tego dnia. Niemałe znaczenie ma fakt, że Górny Śląsk jest regionem o charakterze przemysłowym. Na występujących na tym terenie złożach węgla kamiennego rozwinęło się górnictwo, które miało być źródłem dewiz dla kraju. W rezultacie władza komunistyczna dążyła do wydobycia jak największej ilości tego surowca, co spowodowało intensywny napływ na Górny Śląsk ludności z innych regionów Polski ${ }^{11}$.

Jednocześnie władze komunistyczne podjęty działania prowadzące do narzucenia miejscowej ludności światopoglądu ateistycznego. Przejawem owych szykan był np. zakaz budownictwa sakralnego w nowych osiedlach. Jednocześnie utrudniano lub uniemożliwiano mieszkańcom udział w uroczystościach religijnych $^{12}$, natomiast uroczystości kościelne zastępowano imprezami o charakterze świeckim. Dlatego też w okresie PRL coraz bardziej dawało o sobie znać zagrożenie laicyzacją ${ }^{13}$.

10 D. Szlachta, Herbert Bednorz (1908-1989)..., art. cyt.; D. Szlachta, Bednorz Herbert..., art. cyt., s. 53-61.

11 Liturgia święta, art. cyt., s. 90; J. Myszor, Historia diecezji katowickiej, Katowice 1999, s. 503; A. Kołek, Problematyka społeczno-religijna w kaznodziejstwie biskupa Herberta Bednorza (1967-1989), Katowice 2002, s. 38-39; M. Łuczak, Teologia społeczna w Kościele katowickim 1925-2010, Częstochowa 2013, s. 222; H. Olszar, „,Niedziela Boża i nasza"..., art. cyt., s. 37-39.

12 Najbardziej jaskrawym przykładem może być uniemożliwienie udziału wiernym z Górnego Śląska i Zagłębia w pielgrzymce Jana Pawła II w 1979 r. Już wtedy papież miał zamiar przybyć na Górny Śląsk, co stało się niemożliwe z powodu sprzeciwu I sekretarza KW PZPR Zdzisława Grudnia. Tak dzień 2 czerwca 1979 r. opisuje w kronice ks. Bernard Czernecki z Jastrzębia-Zdroju: „W Polsce dzisiejszy dzień jest wolny od pracy. Tylko nie na Śląsku. Śląsk musiał pracować. Tak zarządził I sekretarz komunistycznej partii w Katowicach Zdzisław Grudzień. Urlopy zostały zawieszone. Tylko Śląsk został potraktowany tak, jakby nie był polski. W czasie powitania Ojca Świętego na Okęciu Śląsk był pozbawiony prądu i nie mógł oglądać tej historycznej godziny na żywo w telewizji. Jakby tego było mało, aktyw partyjny w imieniu załóg kopalni, hut, fabryk i innych zakładów pracy, szkół, biur - wysyłał telegramy i listy do ks. Prymasa Stefana Wyszyńskiego, do Episkopatu, do bpa Herberta Bednorza, że robotnicy i mieszkańcy Śląska... nie chcą u siebie papieża. To jest obelgą. Okrutnym kłamstwem i nadużyciem”. Zob. Kościót Robotników. Kronika kościoła pw. Najświętszej Marii Panny Matki Kościoła w Jastrzębiu-Zdroju 1974-1988, Jastrzębie-Zdrój 2014, s. 66.

13 Zob. A. Wuwer, D. Szlachta, Caritas et Iustitia in re sociali..., dz. cyt., s. 58-60. Jednym z przejawów propagandy ateistycznej było także powstałe w 1969 r. Towarzystwo Krzewienia Kultury Świeckiej, którego działalność bp Bednorz potępił podczas pielgrzymki w 1977 r. A. Wuwer, D. Szlachta, Caritas et Iustitia in re sociali..., dz. cyt., s. 135-136; B. Wójcik, TKKŚ - pomocnik PZPR, „Biuletyn IPN. Pismo o najnowszej historii Polski” [dalej: Biuletyn IPN] 7-8 (2021), nr 188-189, s. 134-145. 
Skutkiem działań władz komunistycznych, rozwoju przemysłu na Górnym Śląsku oraz migracji przejawiającej się w napływie ludności z innych obszarów Polski były zjawiska negatywne, przemilczane w komunistycznej propagandzie. Wśród nich do najważniejszych należy zaliczyć: skażenie środowiska i rozwój chorób; pomijanie problemu bezpieczeństwa pracy wykonywanej przez okrągły tydzień (także w niedzielę), co prowadziło także do wypadków śmiertelnych ${ }^{14}$; absurdalne eksperymenty gospodarcze ${ }^{15}$.

Równocześnie dochodziło do łamania praw obywatelskich, zniewolenia człowieka i pozbawienia godności ludzkiej, czego jednym ze sposobów była praca w niedzielę. Początkowo miała ona charakter dobrowolny. Jednakże od 1968 r. rozpoczęto wprowadzanie tzw. niedziel czarnych, zwanych planowymi lub też niedzielami czynu partyjnego. Ostatecznie w 1977 r. wprowadzono w górnictwie system czterobrygadowy. Załogę kopalni podzielono na cztery zmiany. Trzy zmiany pracowały po osiem godzin, czwarta zaś miała tego dnia wolne. Przy takim harmonogramie dzień wolny od pracy wypadał w dzień powszedni, a niedziele i święta traktowano jako dni robocze ${ }^{16}$. Oczywiście za niestawienie się do pracy groziły sankcje karne (m.in. utrata 14. pensji, zasiłku rodzinnego, przeniesienie na stanowisko gorzej płatne). Oprócz tego nastąpiło wydłużenie czasu pracy (,praca na rolkach”"17).

W ramach sprzeciwu podczas pielgrzymek piekarskich powstało hasło „niedziela Boża i nasza”. Kościół jako jedyna instytucja przeciwstawiał się tego typu

${ }^{14}$ Rozmowa z abp. Wiktorem Skworcem z 3 kwietnia 2014...; Mitosierdzie chrześcijańskie we wspólnocie parafialnej i diecezjalnej, w: Wiara, modlitwa i życie..., dz. cyt., s. 301; B. Woźnica, Ks. bp Herbert Bednorz w obronie społecznych interesów świata pracy, „Śląskie Studia Historyczno-Teologiczne” [dalej: ŚSHT] 22 (1989), s. 38-39; A. Kołek, Problematyka spoleczno-religijna ..., dz. cyt., s. 33-37, 43-46; A. Wuwer, D. Szlachta, De profundis ad Te clamamus. Świat górników w radiowych i telewizyjnych homiliach biskupów katowickich (1983-2016). Edycja źródet z komentarzem, Katowice 2017, s. 55.

${ }^{15} \mathrm{Z}$ pewnością najważniejszym eksperymentem gospodarczym było skupienie przemysłu na małym obszarze i sprowadzenie całej rzeszy ludzi do pracy w nowych zakładach. Kolejnym eksperymentem był nacisk na ilość wyprodukowanego surowca. Nierzadko dokonywało się to kosztem człowieka, jego zdrowia i bezpieczeństwa z powodu łamania przepisów BHP oraz braku konserwacji urządzeń w kopalniach, co prowadziło do wypadków, nierzadko śmiertelnych. Zob. np. B. Woźnica, Ks. bp Herbert Bednorz..., art. cyt.; A. Dziurok, Mowa do ludu, w: Życie w komunistycznym kraju. Polacy w latach 19441989, cz. 6, Robotnicy przeciwko władzy, dodatek do „Gościa Niedzielnego” przygotowany we współpracy z Instytutem Pamięci Narodowej, 12 VI 2011 r., s. 13.

${ }^{16}$ Ks. Michał Kłakus wymienia dziewięć dni wolnych od pracy, w których nie obowiązywał system czterobrygadowy. Były to: 1 I, Święta Wielkanocne, 1 V, 22 VII, 1 XI, 4 XII, 25 XII i 26 XII. Zob. tenże (tu ewentualnie, ponieważ podaję pełne imię autora) M. Kłakus, Kościót i robotnicy. Kościót katolicki na Górnym Ślasku wobec Pierwszej Solidarności w Jastrzębiu-Zdroju, Katowice 2011, s. 22.

17 Czyli nie osiem godzin, ale nawet dwie zmiany z rzędu. Zob. A. Dziurok, Mowa do ludu..., art. cyt. 
praktykom i domagał respektowania praw pracowniczych. Wyrażało się to także podczas pielgrzymek stanowych do Piekar Śląskich, dlatego majowe pielgrzymki mężczyzn i młodzieńców określano jako „pielgrzymki świata pracy”"18.

Zagadnienie świętowania niedzieli w przemówieniach biskupów katowickich po raz pierwszy oficjalnie pojawiło się podczas pielgrzymki męskiej w $1975 \mathrm{r}$. Wówczas bp Bednorz, zwracając się do pielgrzymów, powiedział: „Najczulej wspominamy dzisiaj górników Rybnickiego Okręgu Węglowego, którzy dziś obowiązkowo muszą pracować - siódmy dzień w tygodniu. Duchem są na pewno z nami ci górnicy okręgu rybnickiego, którzy dzisiaj są na dole i fedrują obowiązkowo, ci duchem są z nami. Razem z nimi pytamy się wszyscy, jak można było zmuszać górników do pracy w niedzielę, którą ogłoszono świętem klasy robotniczej, świętem ludzi pracy"19.

Po raz kolejny bp Bednorz mówił o niedzieli podczas pielgrzymki męskiej w 1977 r. Dla niego nakaz pójścia do pracy w niedzielę stanowił przejaw narzucania przez rząd obrzędowości świeckiej. Władze komunistyczne robiły wszystko, aby niedziela straciła swój świąteczny charakter. Jednym ze sposobów manipulowania ludźmi były wyższe pensje i dodatkowe premie dla pracujących w niedzielę ${ }^{20}$. Dlatego też biskup katowicki nie wahał się podawać autentycznych przykładów. Podczas przywołanego przemówienia bp Bednorz nie ukrywał faktów: „Górnik - to, co teraz powiem, to jest rzeczywistość, w życiu to się zdarzyło - chory na grypę, a nawet zapalenie płuc nie przerwał pracy, bo się bał, że straci 14. pensję. Górnik, którego dziecko szło do I Komunii Świętej, musiał pójść do kopalni, aby tylko nie stracić premii - to nieludzkie, to absolutnie być nie powinno"21.

Innym sposobem działania władz było przedłużanie dniówek i tzw. praca na rolkach. Praktyki te budziły sprzeciw bp. Bednorza, który podczas pielgrzymki mężczyzn w 1978 r. stwierdził: „Nasi robotnicy wywalczyli sobie ośmiogodzinny dzień pracy u kapitalistów, dlatego słusznie ufają, że rządy robotnicze pomogą im zachować tę zdobycz społeczną. Nigdy nie zrezygnujemy z ośmiogodzinnego dnia pracy! [...] Chcemy mniej pracować, abyśmy mogli być ludźmi, a nie niewolnikami produkcji. Na tym zyska jakość pracy, o której tyle się dzisiaj mówi i pisze"22.

18 A. Wuwer, D. Szlachta, Caritas et Iustitia in re sociali..., dz. cyt., s. 143-144; H. Olszar, „Niedziela Boża i nasza”..., art. cyt., s. 42; P. Til, Biskupi polscy..., dz. cyt., s. 37-38; D. Szlachta, Tematy spoleczne..., art. cyt., s. 75.

19 A. Wuwer, D. Szlachta, Caritas et Iustitia in re sociali..., dz. cyt., s. 123.

${ }^{20}$ Biskup robotników. Przemówienia bp. Bednorza w Piekarach Śląskich, dodatek CD do „Gościa Niedzielnego” przygotowany na pielgrzymkę mężczyzn i młodzieńców w 2008 r., ścieżka nr 2; A. Suchoń, Stan etosu pracy górnika ślaskiego w okresie rząów totalitarnych, ŚSHT 25/26 (1992/1993), s. 110-111; A. Wuwer, D. Szlachta, Caritas et Iustitia in re sociali..., dz. cyt., s. 143-144; P. Til, Biskupi polscy..., dz. cyt., s. 37-38.

${ }^{21}$ Biskup robotników..., CD, ścieżka nr 2; A. Wuwer, D. Szlachta, Caritas et Iustitia in re sociali..., dz. cyt., s. 135.

${ }^{22}$ Biskup robotników..., CD, ścieżka nr 2; A. Wuwer, D. Szlachta, Caritas et Iustitia in re sociali..., dz. cyt., s. 134-135. 
Problem świętowania niedzieli bp Bednorz podejmował także na pielgrzymce kobiet. Przykładowo w 1977 r. ordynariusz katowicki apelował do żon, aby nie nakłaniały swoich mężów do pracy w niedzielę, ponieważ praca górnika jest ciężka i niebezpieczna. Jednocześnie zwrócił uwagę na wzrost cen węgla. Według bp. Bednorza górnicy powinni zarabiać wystarczająco dużo, aby utrzymać swoją rodzinęe $e^{23}$.

Osobnym zagadnieniem poruszanym przez biskupa katowickiego było wprowadzenie czterobrygadowego systemu pracy w górnictwie. Początkowo w jego ramach miało być tylko pięć niedziel planowych. Jednakże wkrótce okazało się, że wszystkie niedziele są robocze. Było to powodem protestów bp. Bednorza, który wysuwał argumenty bezpieczeństwa pracy i wysokiej śmiertelności w kopalniach z powodu naruszania zasad bezpieczeństwa i nieprzestrzegania przepisów BHP, a także niedostatecznej konserwacji urządzeń, które wskutek tego często się psuły. Podczas pielgrzymki męskiej w 1978 r. biskup katowicki przytoczył list sztygara, który pisał, że „nigdy praca produkcyjna wykonywana w niedziele i święta nie przynosiła korzyści ani państwu, ani pracownikom. Przynosiła raczej rozgoryczenie, przemęczenie, wypadkowość i awaryjność" 24 .

Oprócz tego system czterobrygadowy destabilizował życie rodzinne i społeczne oraz zagrażał zdrowiu i życiu pracowników ${ }^{25}$. Podczas pielgrzymki kobiet w $1980 \mathrm{r}$. bp Bednorz ponownie zachęcał, aby żony nie namawiały mężów do pracy niedzielnej, lecz do pozostania w domu ${ }^{26}$. Dzięki temu „nasi górnicy będą zdrowsi, rodzina będzie szczęśliwsza, a produkcja nie będzie mniejsza, będzie lepsza niż dotychczas. Ona nie stanie. Jeden z inżynierów mi opowiadał: pracuje się coraz więcej, a wydo-

23 A. Wuwer, D. Szlachta, Mater et Familiae Advocata ..., dz. cyt., s. 84-85.

${ }^{24}$ Biskup robotników..., CD, ścieżka nr 8; A. Wuwer, D. Szlachta, Caritas et Iustitia in re sociali..., dz. cyt., s. 141.

${ }_{25}$ Biskup robotników..., CD, ścieżka nr 8; A. Wuwer, D. Szlachta, Caritas et Iustitia in re sociali..., dz. cyt., s. 141. Zob. także: rozmowa z abp. Wiktorem Skworcem z 3 kwietnia 2014...; J. Myszor, Historia diecezji..., dz. cyt., s. 514-515; A. Kołek, Problematyka społeczno-religijna ..., dz. cyt., s. 36, 59-60, 63, 66, 86; J. Neja, Dwa strajki-dwa porozumienia, Biuletyn IPN 9-10 (2010), nr 118-119, s. 65-66; H. Olszar, , Niedziela Boża i nasza”,..., art. cyt., s. 39, 41; H. Olszar, Iustitia socialis Kościoła katowickiego w czasach zniewolenia $i$ wolności, w: Sprawiedliwość i miłość społeczna..., dz. cyt., s. 55; M. Łuczak, Teologia społeczna..., dz. cyt., s. 223; A. Wuwer, D. Szlachta, De profundis ad Te..., dz. cyt., s. 55; D. Szlachta, Tematy społeczne ..., art. cyt., s. 75; P. Til, Biskupi polscy..., dz. cyt., s. 37.

${ }^{26}$ Argumentem za pójściem do pracy w niedzielę były lepsze zarobki. Przykładem może tu być przemówienie bp. Bednorza podczas pielgrzymki kobiet w 1977 r. Wówczas biskup mówił: „Będą jednak górników kusić bodźcami materialnymi, np. płacą za niedzielną szychtę 500 zł. Ktoś mi mówił, że nawet 1000 zł za szychtę! [...] I żony górników o tym wiedzą, dlatego jedna z nich, która miała namówić męża do niedzielnej pracy, powiedziała: «Mój mąż nie pójdzie w niedzielę do pracy. Zresztą to, co zarabiał, po południu przepijał. Dlatego tym bardziej nie pójdzie do niedzielnej pracy, ale za to tym lepiej będzie pracował w tygodniu, aby spotęgowała się jakość pracy, choć zmniejszona zostanie ilość pracy»". Zob. A. Wuwer, D. Szlachta, Mater et Familiae Advocata ..., dz. cyt., s. 85. 
bycie węgla jest coraz mniejsze. Sami sobie dośpiewajcie, co z tego wynika i z tego przemęczenia górnika, które wreszcie musi ustać. Inaczej górnicy sami będą przedwcześnie ginąć. Mówiąc to, spełniam podstawowy, zasadniczy obowiązek pasterza diecezji" 27 .

Bp Bednorz stale sprzeciwiał się także desakralizacji życia ${ }^{28}$ popieranej m.in. przez związki zawodowe ${ }^{29}$. Dlatego podczas pielgrzymki ordynariusz katowicki przestrzegał: „Obrzędowość świecka ma jeden naczelny cel: odchrześcijanić naród polski. To, co przez tysiące lat zostało systematycznie zbudowane, ma być szybko obalone i zastąpione przez ateistyczną obrzędowość świecką [...], która za wszelką cenę chce znieść niedziele i święta kościelne jako dni wypoczynku i służby Bożej. Temu ma także służyć nowy system pracy, który nie uznaje niedzieli ani święta Bożego Ciała, osłabia życie w małżeństwie i rodzinie. To jego zgubne skutki społeczne w rodzinach, w których mąż i ojciec pracuje w niedziele. Słyszy się tu głośne wołanie, dzieci wołają o ojca, a żony wołają o męża [...]. Pamiętajcie! Niedziela jest dla rodziny, a nie dla kopalni ani dla innej fabryki! To górnicy tak mówią, ja w ich imieniu to tu przedkładam" 30 .

Równocześnie biskup katowicki apelował do górników, aby nie dawali się omamić lepszymi zarobkami. W sprawie zniesienia systemu czterobrygadowego ordynariusz pisał także do władz państwowych, dając im do zrozumienia, że może to doprowadzić do protestów społecznych ${ }^{31}$. Ostatecznie system udało się zlikwidować

27 A. Wuwer, D. Szlachta, Mater et Familiae Advocata ..., dz. cyt., s. 102.

28 Władze starały się zastąpić obrzędy religijne uroczystościami o charakterze świeckim. Miały temu służyć m.in. śluby cywilne, nadanie imienia (zamiast chrztu) czy też Dziadek Mróz zamiast św. Mikołaja. Ważną rolę odgrywało na tym polu Towarzystwo Krzewienia Kultury Świeckiej powstałe w 1969 r. Więcej: zob. Ł. Marek, Obrzędowość świecka, w: Przez Morze Czerwone. Kościót w Polsce pod rzadami komunistów, cz. 5, Życie codzienne katolika w PRL. Dodatek do tygodnika „Gość Niedzielny” z 14 IX 2008 r., s. 6-7; B. Wójcik, TKKŚ - pomocnik PZPR, art. cyt.

29 Ówczesne związki zawodowe działały w ramach Centralnej Rady Związków Zawodowych utworzonej w 1949 r. Ich członkowie często należeli do PZPR. J. Neja, Pierwsi w kraju. Komitet Wolnych Związków Zawodowych w Katowicach, Biuletyn IPN 4 (2018), nr 149, s. 18-20; Biskup robotników..., CD, ścieżka nr 8; A. Wuwer, D. Szlachta, Caritas et Iustitia in re sociali..., dz. cyt., s. 140-141.

${ }^{30}$ Biskup robotników..., CD, ścieżka nr 8; A. Wuwer, D. Szlachta, Caritas et Iustitia in re sociali..., dz. cyt., s. 141.

31 Protesty takie faktycznie się odbyły, np. w Jastrzębiu-Zdroju, kiedy to 18 czerwca 1978 r. górnicy z kopalni „Jastrzębie” i „Moszczenica” nie zjechali do pracy w kopalni. Powodem strajku było wstrzymanie wynagrodzenia oraz czterobrygadowy system pracy. W odpowiedzi wielu pracowników przeniesiono na stanowiska gorzej płatne, a 41 osób otrzymało zwolnienia dyscyplinarne. Ostatecznie dzięki wstawiennictwu ks. Bernarda Czerneckiego protesty zakończyły się 10 lipca. Wówczas zwolnieni górnicy zostali przywróceni do pracy. Zob. Rozmowa z abp. Wiktorem Skworcem z 3 kwietnia 2014...; Kościół robotników..., dz. cyt. s. 60-63; M. Kłakus, Kościót i robotnicy..., dz. cyt., s. 23-24. 
dzięki porozumieniom jastrzębskim podpisanym 3 września 1980 r. Jeden z postulatów przedstawionych przez związkowców dotyczył także wolnych sobót i niedziel ${ }^{32}$. Toteż rok później biskup katowicki podczas pielgrzymki kobiet dziękował Bogu za zniesienie czterobrygadowego systemu pracy w górnictwie oraz niedziel roboczych. Wyrażało się to w haśle pielgrzymki, które brzmiało: „Dziękujmy Opatrzności Bożej za wstawiennictwo Maryi za niedzielę wolną od pracy"33.

W słowie skierowanym do pątniczek bp Bednorz mówił, że chrześcijaństwo się nie przeżyło. Przyczyniają się do tego również pielgrzymki do Piekar Śląskich. Apelował przy tym, aby pielgrzymowanie to wydawało stałe owoce $\mathrm{w}$ postaci lepszego życia jako chrześcijan i apostołów, którzy „włączą w naszą wspólnotę katolicką i oziębłych braci, i siostry nasze. O tym nie wolno nam zapominać! Zapraszajmy na przykład na regularną Mszę Świętą niedzielną i tych w sąsiedztwie naszym żyjących, którzy odzwyczajali się od tego, bo przez lata w niedziele i święta pracowali. To dzięki Bogu ustało. Za to dziś zaintonujemy przeradosne Ciebie, Boże, wielbimy" ${ }^{34}$.

Okazało się jednak, że władza komunistyczna nie zamierzała rezygnować całkowicie z systemu czterobrygadowego w górnictwie i szukała sposobów nakłonienia górników, aby podjęli pracę $\mathrm{w}$ niedziele. Jedną z zachęt było większe wynagrodzenie $^{35}$. Podczas pielgrzymki kobiet w 1980 r. bp Bednorz przedstawił przykład dyrektora kopalni, ,który zaprosił do siebie inżynierów, sztygarów i powiedział do nich następujące słowa: «Klęknijcie przed górnikami, aby w niedzielę chodzili na szychtę do kopalni» [...]. Każdy, który słyszy te słowa, musi powiedzieć sobie: «Jest źle, jest bardzo źle», bo górnicy nie chcą iść na szychtę do kopalni. Do tego mają święte prawo. Dyrektor kopalni chce przełamać to prawo, dlatego każe kadrze inży-

32 Rozmowa z abp. Wiktorem Skworcem z 3 kwietnia 2014...; Biskup robotników..., CD, ścieżka nr 8; Miłosierdzie chrześcijańskie..., art. cyt., s. 301; J. Myszor, Historia diecezji..., dz. cyt., s. 515-519; A. Kołek, Problematyka społeczno-religijna..., dz. cyt., s. 36, 45; J. Neja, Dwa strajki..., art. cyt., s. 67-71; tenże, Matecznik komunistów czy region buntu?, Biuletyn IPN 9 (2017), nr 142, s. 100-106; D. Szlachta, Ksiadz Bernard Czernecki-kapelan Solidarności w Jastrzębiu i duszpasterz ludzi pracy, Biuletyn IPN 7-8 (2021), nr 188-189, s. 69-71; H. Olszar, „, Niedziela Boża i nasza”..., art. cyt., s. 42; P. Til, Biskupi polscy..., dz. cyt., s. 51-52, 199; A. Wuwer, D. Szlachta, Caritas et Iustitia in re sociali..., dz. cyt., s. 141-142; A. Wuwer, D. Szlachta, De profundis ad Te..., dz. cyt., s. 55-56; A. Grajewski, Biskup katowicki Herbert Bednorz wobec władzy komunistycznej na Górnym Śląku w latach 1967-1985. Zarys problematyki, w: Biskup Herbert Bednorz..., dz. cyt., s. 40-41. Tekst porozumień: zob. T. Kurpierz, J. Neja, ,Solidarność” ślasko-dabrowska 1980-1981. Szkic do monografii i dokumenty własne, Katowice 2012, s. 187-193.

33 A. Wuwer, D. Szlachta, Mater et Familiae Advocata ..., dz. cyt., s. 103.

34 A. Wuwer, D. Szlachta, Mater et Familiae Advocata ..., dz. cyt., s. 105 ; M. Łuczak, Teologia spoleczna..., dz. cyt., s. 227-228.

35 Liturgia święta, art. cyt., s. 88; J. Myszor, Historia diecezji..., dz. cyt., s. 516-518; P. Til, Biskupi polscy..., dz. cyt., s. 52-53, 289; A. Wuwer, D. Szlachta, Mater et Familiae Advocata..., dz. cyt., s. 105. 
nierów i sztygarów klękać przed górnikami, aby się jednak zlitowali i w niedzielę przychodzili do pracy. Nadaremno to będzie to klękanie i ta prośba. Bo ja Wam powiem: Wy uklęknijcie przed Waszymi mężami i przed Waszymi synami górnikami i powiedzcie im: niedziela jest Boża i nasza" ${ }^{36}$.

Sprzeciw biskupa katowickiego budziły także tzw. czyny społeczne, organizowane m.in. przez zakłady pracy, spółdzielnie mieszkaniowe i szkoły. Praca w ramach tych akcji była wykonywana bezpłatnie w dzień wolny od pracy. Często odbywała się także w niedzielę. Początkowo słuszną ideę władze zaczęły wykorzystywać jako element propagandowy, narzucając przy tym przymus pracy ${ }^{37}$. Podczas pielgrzymki męskiej w 1980 r. bp Bednorz mówił: „Chętnie podejmiemy czyn społeczny, aby wybudować nowy kościół albo stworzyć coś innego, co ma wartość dla całej wspólnoty i służy wszystkim. Jeśli to służy wszystkim, weźmiemy w tym udział. Ale takie czyny społeczne wykonamy tylko w tygodniu, a nigdy w niedzielę [...]. Nie przyjmujemy zasady, by w świątek, piątek trzeba było ciężko pracować, i tego nie przyjmujemy, i najbardziej wyrafinowane przynęty materialne wkrótce nie wystarczą, by robotników nakłonić do stałej pracy w niedziele i święta, z którą łączy się mordercza gonitwa przez cały tydzień" 38 .

Bp Bednorz mówił także o wyjazdach turystycznych, wycieczkach i koloniach. Sprzeciw biskupa budziło organizowanie przez zakłady pracy takich wyjazdów w niedzielę, co uniemożliwiało ich uczestnikom udział we Mszy Świętej. Biskup katowicki dawał do zrozumienia, że turystyka nie może być okazją do zaniedbywania obowiązków religijnych ${ }^{39}$. Dlatego podczas pielgrzymki kobiet w $1977 \mathrm{r}$. bp Bednorz postulował: „Otoczymy specjalną troską dzieci i młodzież, które były na koloniach letnich, gdzie nie wolno było uczęszczać w niedzielę i święta na Mszę Świętą ani głośno z innymi się modlić, choć to podstawowe prawo ludzkie. Kto to prawo narusza, ten łatwo skłania się ku temu, by naruszać wszystkie prawa ludzkie. Doświadczenie to wykazuje. Ważne to jest. Myśmy domagali się wolności religijnej dla dzieci naszych i młodzieży uczęszczających na kolonie letnie. My mówimy do rodzin ateistycznych: wy możecie swoje dzieci wysyłać na kolonie ateistyczne, laickie, ale my katolicy żądamy dla dzieci katolickich wolności uczęszczania na koloniach letnich na Mszę Świętą, wolności swobodnej modlitwy rano i wieczorem, tego się domagamy" ${ }^{40}$.

36 A. Wuwer, D. Szlachta, Mater et Familiae Advocata ..., dz. cyt., s. 101.

37 J. Myszor, Historia diecezji..., dz. cyt., s. 514; A. Kołek, Problematyka społeczno-religijna..., dz. cyt., s. 86; D. Szlachta, Tematy spoleczne..., art. cyt., s. 75.

38 A. Wuwer, D. Szlachta, Caritas et Iustitia in re sociali..., dz. cyt., s. 152-153. Por. A. Wuwer, D. Szlachta, Mater et Familiae Advocata ..., dz. cyt., s. 101.

39 Liturgia święta, art. cyt., s. 85; Miłosierdzie chrześcijańskie..., art. cyt., s. 301; A. Wuwer, D. Szlachta, Mater et Familiae Advocata ..., dz. cyt., s. 84-85; J. Myszor, Historia diecezji..., dz. cyt., s. 514; P. Til, Biskupi polscy..., dz. cyt., s. 34, 272; M. Łuczak, Teologia społeczna..., dz. cyt., s. 222-223.

40 A. Wuwer, D. Szlachta, Mater et Familiae Advocata ..., dz. cyt., s. 85. 
Dlatego biskup katowicki domagał się od władz możliwości udziału dzieci i młodzieży we Mszy Świętej niedzielnej podczas kolonii letnich. Podczas pielgrzymki mężczyzn w 1978 r. biskup relacjonował: „Dialog kontynuujemy z władzami naszymi. To spotkanie w Piekarach jest także jednym z rodzajów dialogu. W ramach tego dialogu będziemy wołać o to, by dzieci i młodzież miały w niedziele i święta na koloniach letnich swobodę pójścia do kościoła. Nasi mężowie o to zadbają i będą pilnowali, aby dzieci miały wolność pójścia w niedzielę i święta na koloniach do kościoła"41.

Biskup katowicki nadawał wyjazdom turystycznym znaczenie religijne i zachęcał, aby miały one charakter rodzinny. Podczas pielgrzymki kobiet w 1973 r. przytaczał też sytuację, kiedy ludzie pytali go o kaplicę lub kościół w celu uczestnictwa we Mszy Świętej: „Turyści, wczasowicze katoliccy szukali w różnych kotlinach górskich kościoła lub kaplicy, pytali się o to, gdy znaleźli w Malince małą kapliczkę, to nie przestali wyrażać radości swojej, tym bardziej że mogli być na Mszy Świętej. Wiecie, to dowód, że mamy potężny zastęp katolików, którzy wiedzą, o co dzisiaj chodzi: o wierność dla Kościoła na Mszy Świętej. Ci turyści - a byli to najczęściej górnicy - wysoce sobie cenili niedzielną Mszę Świętą, dlatego pytali, gdzie tu jest kościół. W wielu innych miejscowościach są wyraźne ślady tego szukania kościoła, to katolicy świeccy szukają kościoła, łącząc się z kapłanami i biskupami wołają o nowe kościoły, zwłaszcza w nowych osiedlach i miastach"42.

Bp Herbert Bednorz kierował diecezją katowicką do 1985 r., kiedy to przeszedł na emeryturę. Jego następcą został dotychczasowy proboszcz parafii Niepokalanego Poczęcia Najświętszej Maryi Panny w Katowicach, ks. dr Damian Zimoń.

\section{Nauczanie o niedzieli w dobie przemian demokratycznych}

Posługę bp. Damiana Zimonia można podzielić na dwa okresy, cezurę których wyznacza rok 1989 i przemiany społeczne z nim związane ${ }^{43}$. Pierwsze lata posługi nowego biskupa katowickiego były ostatnimi latami działalności władzy komunistycznej, która jednak nie dawała za wygraną ${ }^{44}$. Piąty biskup katowicki nadal sprzeciwiał się systemowi czterobrygadowemu w górnictwie. Po raz pierwszy bp Zimoń mówił na ten temat podczas pielgrzymki mężczyzn w 1986 r. Stwierdził wówczas:

${ }^{41}$ Biskup robotników..., CD, ścieżka nr 9; A. Wuwer, D. Szlachta, Caritas et Iustitia in re sociali..., dz. cyt., s. 142.

42 A. Wuwer, D. Szlachta, Mater et Familiae Advocata ..., dz. cyt., s. 64.

43 Ta część artykułu opiera się na pracy: A. Wuwer, Nauczanie społeczne arcybiskupa metropolity Damiana Zimonia podczas stanowych pielgrzymek mężczyzn i młodzieńców do Piekar Śląskich w latach 1986-2004, w: Rocznice, które wspominaja, uobecniaja i zapowiadają. Zagadnienia teologiczne, socjologiczne i historyczne, red. J. Kozyra, M. Łuczak, Katowice-Piekary Śląskie 2005, s. 72-73.

44 Zob. Rozmowa z abp. Damianem Zimoniem z 13 grudnia 2013 r. przeprowadzona przez D. Szlachtę (w zbiorach autora); Ciagle tonę i chwytam Jezusa. Z abp. Damianem Zimoniem rozmawiaja Alina Petrowa-Wasilewicz i ks. Jerzy Szymik, Katowice 2002, s. 150-151. 
„Wszystkim robotnikom trzeba także godziwego odpoczynku w niedzielę i święta. Niedziela niech pozostanie nadal Boża i nasza. Do tego robotnik ma niezaprzeczalne prawo"45.

Na temat wypoczynku niedzielnego górników oraz nadużyć z powodu nakłaniania górników do pracy w niedzielę bp Damian Zimoń wypowiedział się także podczas pielgrzymki męskiej w 1988 r. Wówczas mówca podkreślił: „Prawem naszych robotników jest niedzielny wypoczynek. Dawniej nigdy na Śląsku nie pracowano w niedzielę. Dlatego niektóre praktyki w górnictwie są nie do przyjęcia. Górnicy pisali niedawno: «Nadal na kopalni liczy się tylko wydobycie węgla. Dyrekcja kopalni wypracowała wiele wariantów pracy w niedzielę. Manipuluje się w tym celu funduszem premiowym. Fakt ten ukrywa się przed kontrolą z zewnątrz». Są to praktyki nie do przyjęcia. Niedziela jest Boża i nasza. Tyle mówiliśmy już w Piekarach. Czy znów dzień Pański ma być zagrożony?"46.

Nadużycia wymienione przez biskupa katowickiego podczas przemówienia oraz problem przedłużającego się czasu pracy doprowadziły w śląskich kopalniach do strajków przeciwko eksploatacji człowieka oraz zagrożeniu życia rodziny. Jednakże panujące władze odpowiedziały zwolnieniami z pracy osób uczestniczących w protestach. W związku z tym biskup katowicki odczytał swoje słowo pasterskie podczas pielgrzymki kobiet w $1988 \mathrm{r} \cdot{ }^{47} \mathrm{~W} 1987 \mathrm{r}$. bp Zimoń - podobnie jak jego poprzednik - apelował, aby żony nie wysyłały mężów do pracy niedzielnej. Biskup katowicki przestrzegał wówczas: „Słyszę tu i ówdzie, że zachęca się do pracy w niedzielę. Co więcej, słyszę, że do tej pracy zachęcają swych mężów żony, najczęściej w takich rodzinach, którym powodzi się względnie dobrze. Pamiętajmy, że niedziela ma pozostać Bożą i naszą. Plony wspólnie spędzonych niedziel zbierzemy może za

45 D. Zimoń, Droga Kościoła jest człowiek. Kościół katowicki wobec problemów społecznych $w$ latach 1985-1995, Katowice 1995, s. 285; A. Wuwer, D. Szlachta, Caritas et Iustitia in re sociali..., dz. cyt., s. 173.

46 D. Zimoń, Droga Kościoła jest człowiek..., dz. cyt., s. 303; A. Wuwer, D. Szlachta, Caritas et Iustitia in re sociali..., dz. cyt., s. 183. Por. M. Łuczak, Teologia społeczna..., dz. cyt., s. 553-554.

47 Strajki wybuchły w kopalniach Jastrzębia-Zdroju („Manifest Lipcowy”, „Moszczenica”). Następnie stanęły kolejne zakłady górnicze (m.in. „Andaluzja” w Piekarach Śląskich). W sierpniu 1988 r. do górników dołączyli także stoczniowcy ze Szczecina i Trójmiasta oraz hutnicy z Krakowa, Warszawy i Stalowej Woli. Zob. D. Zimoń, Słowo pasterskie biskupa katowickiego w związu ze strajkami, „Wiadomości Diecezjalne. Organ Urzędowy Kurii Diecezjalnej w Katowicach" 56 (1988), nr 8, s. 264-265; D. Zimoń, Droga Kościoła jest człowiek..., dz. cyt., s. 47-50, 361-365; A. Wuwer, D. Szlachta, Mater et Familiae Advocata ..., dz. cyt., s. 287-288; B. Tracz, Niezrealizowane postulaty. Strajkowe lato 1988 roku w województwie katowickim, Biuletyn IPN 9 (2017), nr 142, s. 112-126; B. Tracz, Cios sierp(ni)owy. Strajki na Górnym Ślasku w 1988 r., Biuletyn IPN 4 (2019), nr 161, s. 13-24; A. Suchoń, Stan etosu pracy..., art. cyt., s. 112-115; J. Myszor, Historia diecezji..., dz. cyt., s. 526; M. Łuczak, Teologia społeczna..., dz. cyt., s. 223-224, 554; H. Olszar, Iustitia socialis..., art. cyt., s. 55-56; P. Til, Biskupi polscy..., dz. cyt., s. 52-53, 77. 
wiele lat, ale pamiętajmy, że tylko wtedy gdy rodzina będzie Bogiem silna, nie da się zwyciężyć planowej laicyzacji czy nawet ateizacji”48.

Po 1989 r. problemem stał się rozwój handlu niedzielnego, który spowodował spadek uczestnictwa we Mszy Świętej niedzielnej. Praktykom tego typu arcybiskup katowicki przeciwstawiał się podczas pielgrzymki mężczyzn w 1994 r. Jednocześnie zachęcał pielgrzymów, aby kultywowali zwyczaje związane z rodzinnym przeżywaniem dnia Pańskiego. Dzięki nim rodzina może się zjednoczyć. Ważną rolę do odegrania ma tu kobieta jako żona, matka i nauczycielka. Biskup katowicki wielokrotnie apelował o przywrócenie niedzieli charakteru świątecznego ${ }^{49}$.

Podczas przemówienia wygłoszonego na pielgrzymce kobiet w 1999 r. abp Zimoń zwrócił się do kobiet z wezwaniem, ,aby Bóg był obecny i czczony w Waszych rodzinach. Nie zapominajcie o wspólnej, codziennej modlitwie, zwłaszcza wieczornej; o świętowaniu niedzieli i uczestniczeniu we Mszy Świętej niedzielnej. Jesteście dla swoich dzieci i młodzieży pierwszymi nauczycielami modlitwy i cnót chrześcijańskich i nikt was w tym nie może zastąpić. Zachowujcie religijne zwyczaje i pielęgnujcie tradycję chrześcijańską, uczcie szacunku dla każdego człowieka" "50.

Wśród zwyczajów związanych ze świętowaniem niedzieli arcybiskup katowicki podkreślił udział rodziny w niedzielnej Mszy Świętej. W czasie pielgrzymki kobiet w 2000 r. apelował, aby nie opuszczać Mszy niedzielnej jako ważnego elementu życia modlitwy w rodzinie. O ważnej roli niedzielnej Mszy Świętej metropolita katowicki mówił także podczas pielgrzymki męskiej w $2007 \mathrm{r} .{ }^{51}$ Na pielgrzymce kobiet w 2000 r. arcybiskup zapewniał: ,Spotkanie w supermarkecie nie może zastąpić spotkania przy rodzinnym stole! Tak wiele zależy w tym zakresie od żony i matki!' 52 .

Po raz kolejny abp Damian Zimoń wypowiedział się na temat świętowania niedzieli podczas pielgrzymki mężczyzn w $1998 \mathrm{r}$. Wówczas wyraził sprzeciw wobec pracy w niedzielę oraz działalności handlowej tego dnia. Uzasadnił to tym, że w innych krajach Europy sklepy w niedzielę są zamknięte. Jednocześnie w przesłaniu do pielgrzymów arcybiskup katowicki przypomniał walkę o wolną niedzielę w czasie PRL, kiedy to „w czasach totalitarnych tak organizowano życie społeczne, by pozbawić niedzielę jej świątecznego charakteru. Znacie historię tzw. czterobrygadowego systemu pracy. Dziś obserwujemy niebezpieczne zjawisko zagrożenia świątecznego wymiaru niedzieli przez coraz powszechniejsze dobrowolne podejmowanie w tym dniu pracy i handlu. Zatraca się świadomość, że niedziela jest dniem świętym [...].

48 D. Zimoń, Droga Kościoła jest człowiek..., dz. cyt., s. 300; A. Wuwer, D. Szlachta, Mater et Familiae Advocata ..., dz. cyt., s. 118.

49 D. Zimoń, Droga Kościoła jest człowiek..., dz. cyt., s. 338; A. Wuwer, D. Szlachta, Caritas et Iustitia in re sociali..., dz. cyt., s. 205; A. Wuwer, D. Szlachta, Mater et Familiae Advocata..., dz. cyt., s. 138, 158-159, 169.

50 A. Wuwer, D. Szlachta, Mater et Familiae Advocata..., dz. cyt., s. 165.

51 A. Wuwer, D. Szlachta, Caritas et Iustitia in re sociali..., dz. cyt., s. 275-276; A. Wuwer,

D. Szlachta, Mater et Familiae Advocata ..., dz. cyt., s. 169.

52 A. Wuwer, D. Szlachta, Mater et Familiae Advocata ..., dz. cyt., s. 169. 
Brońmy świętości niedzieli! Uczciwe ułożenie życia społecznego bez świętowania niedzieli jest niemożliwe! Trzeba bronić świętości niedzieli jako cennego wkładu w życie duchowe społeczności ludzkiej”53.

W kontekście świętowania niedzieli ważnym elementem jest także prawo do wypoczynku, które należy się każdemu człowiekowi, o czym abp Zimoń przekonywał podczas pielgrzymki mężczyzn w $1995 \mathrm{r} .{ }^{54} \mathrm{~W} 2002$ r. dawał również do zrozumienia, że nieświętowanie niedzieli jest wyrazem lekceważenia trzeciego przykazania. Według metropolity katowickiego prowadzi to do laicyzacji, której skutkiem jest „poczucie duchowej pustki, zagubienia, a czasem odrzucenia wszystkich systemów wartości. Dziś praktyczna laicyzacja dramatycznie osłabia ducha religijnego. Jednym z przykładów tego zjawiska jest powszechne łamanie przykazania świętowania niedzieli. Przyczyną jest przymuszanie do pracy w niedziele osób, które z powodów ekonomicznych ulegają presji pracodawców. Mamy tu do czynienia z grzechem społecznym, u podstaw którego leży błędny system wartości, sprowadzający człowieka do roli konsumenta. Ostatnio słyszałem przysłowie, jakżeż wymowne: «To, co w niedzielę człowiek zarobi, to na złamanym kiju nie uniesie»" ${ }^{55}$.

Abp Damian Zimoń dostrzegał także pozytywne skutki przemian społecznych i gospodarczych związanych z demokratyzacją życia społecznego oraz przejściem na gospodarkę rynkową i przyłączeniem się do Unii Europejskiej. Mówił też o niepokoju wśród tych, „którzy z lękiem patrzą na otaczającą nas rzeczywistość. Wiele jest przyczyn tego lęku i beznadziei. Ciągle naruszane są prawa pracowników związane z czasem zatrudnienia i wynagrodzenia. Wołamy o poszanowanie godności pracownika! Ciągle jest aktualne wezwanie, że «niedziela jest Boża i nasza»" ${ }^{46}$.

Abp Zimoń przypomniał hasło podczas obu pielgrzymek stanowych w 2006 r., które brzmiało: „Przywracajmy nadzieję ubogim”57. Jego szczególna wymowa wynikała z tego, że wiele osób nie miało nadziei na lepsze jutro. Powodem tego stanu rzeczy był wzrost bezrobocia, który na Śląsku mocno dawał się we znaki z powodu restrukturyzacji przemysłu prowadzącej do likwidacji kopalń. Ważną rolę odgrywała też pomoc bezrobotnym na terenie archidiecezji katowickiej ${ }^{58}$.

53 A. Wuwer, D. Szlachta, Caritas et Iustitia in re sociali..., dz. cyt., s. 226-227; M. Łuczak, Teologia społeczna..., dz. cyt., s. 556-557.

54 D. Zimoń, Droga Kościoła jest człowiek..., dz. cyt., s. 347; A. Wuwer, D. Szlachta, Caritas et Iustitia in re sociali..., dz. cyt., s. 210.

55 A. Wuwer, D. Szlachta, Caritas et Iustitia in re sociali..., dz. cyt., s. 246 ; M. Łuczak, Teologia społeczna ..., dz. cyt., s. 556; D. Szlachta, Tematy społeczne ..., art. cyt., s. 77.

56 A. Wuwer, D. Szlachta, Caritas et Iustitia in re sociali..., dz. cyt., s. 268.

57 A. Wuwer, D. Szlachta, Caritas et Iustitia in re sociali..., dz. cyt., s. 267 ; A. Wuwer, D. Szlachta, Mater et Familiae Advocata..., dz. cyt., s. 200; D. Zimoń, „Przywracajmy nadzieję ubogim" - oto zadanie dla Kościoła na Ślasku, w: Z tej ziemi. Ślaski kalendarz katolicki na rok 2006, Katowice 2005, s. 29-32.

58 Więcej na ten temat: zob. D. Szlachta, Arcybiskup Damian Zimoń - „, biskup bezrobotnych”, ŚSHT 53 (2020), z. 1, s. 78-91. 
Nierzadko dochodziło również do naruszania praw pracowniczych, np. przymuszania pracowników pod groźbą zwolnienia do dodatkowej pracy także w niedzielę $^{59}$. W związku z tym arcybiskup apelował do ludzi odpowiedzialnych za przestrzeganie praw pracowniczych i pracodawców. Podczas przemówienia przywołał telegram Jana Pawła II do pielgrzymów odczytany w 2004 r. Papież zwrócił wówczas się z prośbą do pracodawców, ,aby dołożyli wszelkich starań, by szacunek dla człowieka i jego pracy przeważał nad chęcią osiągnięcia jak największego zysku. Proszę pracodawców, aby szanowali prawo pracownika do godziwego wynagrodzenia, do bezpieczeństwa, do opieki społecznej i do odpoczynku. Wszystkich - i pracodawców, i pracowników - wzywam do poszanowania niedzieli z jej centralnym momentem, jakim jest Msza Święta. Niech sławne na Śląsku powiedzenie «Niedziela jest Boża i nasza» nie traci swojej wymowy i mocy"60.

Abp Damian Zimoń popierał wszelkie starania, które miały się przyczynić do ograniczenia handlu niedzielnego. Jednym z podstawowych argumentów na poparcie tych działań był fakt, że w wielu krajach Europy sklepy i galerie są w niedzielę nieczynne ${ }^{61}$.

\section{Niedziela widziana dzisiaj}

Od października 2011 r. posługę $\mathrm{w}$ archidiecezji katowickiej pełni abp Wiktor Skworc, który podejmuje działania związane z rozwiązywaniem konfliktów spowodowanych błędami zarówno rządzących, jak i związków zawodowych. Jednym z wątków poruszanych przez abp. Wiktora Skworca jest także zagadnienie świętowania niedzieli. Temat ten pojawia się w kontekście powstających centrów handlowych często czynnych przez siedem dni w tygodniu. Również w jego przemówieniach można znaleźć nawiązanie do hasła „niedziela Boża i nasza" ${ }^{2}$. Po raz pierwszy problem ten poruszono podczas obu pielgrzymek stanowych w 2012 r. Wówczas abp Skworc wzywał: „W imieniu pracowników handlu, a jest to bardzo duża grupa ludzi, licząca około miliona pracujących, z których zdecydowana większość, bo aż 70\%,

59 Problem ten abp Zimoń poruszył także podczas pielgrzymki męskiej w 2000 r. Zob. D. Zimoń, Pochylmy się nad bezrobociem, Katowice 2002, s. 34-36, 81; A. Wuwer, D. Szlachta, Caritas et Iustitia in re sociali..., dz. cyt., s. 236.

${ }^{60}$ Mówię do Was: Szczęść Boże! Kardynat Karol Wojtyła-Ojciec Święty Jan Paweł II w Piekarach Ślaskich, komentarze oprac. J. Kiedos, S. Cichy, E. Nalepa, zebrali B. Pietyra, J. Przybyła, B. Woźnica, wyd. 2, Katowice 2005, s. 169; A. Wuwer, D. Szlachta, Caritas et Iustitia in re sociali ..., dz. cyt., s. 254; A. Wuwer, D. Szlachta, Mater et Familiae Advocata..., dz. cyt., s. 190.

61 A. Wuwer, D. Szlachta, Mater et Familiae Advocata ..., dz. cyt., s. 191; M. Łuczak, Teologia społeczna ..., dz. cyt., s. 556-557; W. Świątkiewicz, Profanizacja dies Domini. Między przyzwoleniem a zgorszeniem, w: Świętowanie niedzieli..., dz. cyt., s. 65-67.

62 Rozmowa z abp. Wiktorem Skworcem z 3 kwietnia 2014 ...; A. Wuwer, D. Szlachta, Caritas et Iustitia in re sociali..., dz. cyt., s. 65-66; . W. Świątkiewicz, Profanizacja dies Domini..., art. cyt., s. 61-64. 
stanowią kobiety, upominamy się w Piekarach o wolne od pracy niedziele. Nie wolno odbierać im wolności do świątecznego odpoczynku. To prawo wynika z zasady równości wobec prawa!"’33.

Rok później abp Skworc odniósł postulat wolnej niedzieli do przeżywanego wówczas Roku Wiary. Dlatego pytał zgromadzonych pątników, jaka jest ich wiara. Niepokój arcybiskupa wzbudził coraz mniejszy udział w niedzielnej Mszy Świętej ${ }^{64}$. Podczas pielgrzymkowego przemówienia metropolita przypomniał nauczanie Jana Pawła II, który w liście Dies Domini pisał: „dziś chciałbym z mocą wezwać wszystkich do ponownego odkrycia niedzieli: Nie lękajcie się ofiarować waszego czasu Chrystusowi!”, i dodawał: „Czas ofiarowany Chrystusowi nigdy nie jest czasem straconym" ${ }^{\prime 5}$.

Jednocześnie abp Skworc podkreślił, że ,„świętowaniu niedzieli było poświęcone tegoroczne piekarskie sympozjum" ${ }^{\text {. }}$. Sympozja takie organizowano w latach 1992-2016. Odbywały się one dzień przed pielgrzymką mężczyzn i młodzieńców ${ }^{67}$.

Dalej metropolita apelował: „Musimy sobie, Bracia, przypomnieć trzecie Boże przykazanie: Pamiętaj, abyś dzień święty święcił! Oznacza to, że w tym dniu mamy przykładać się do świętych słów, zajęć i świętego życia. Nie wolno nam umniejszać Kościoła przez nieobecność na niedzielnej Mszy Świętej, a tak się niestety dzieje. Bądźcie zatem, Bracia, apostołami świętowania niedzieli i dajcie tego przykład! Wspólnie wołamy do Pana: «przymnóż nam wiary», abyśmy byli solą ziemi!"68.

W tym kontekście zgodnie z katolicką nauką społeczną „państwo powinno w kwestiach pracowniczych stanąć po stronie słabszego, a tym słabszym w układzie pracodawca - pracobiorca jest zawsze pracownik; i postulat drugi: gwarantować prawo do wypoczynku, a zwłaszcza chronić niedzielę jako dzień wolny od pracy, dający wszystkim możliwość wspólnego odpoczynku i świętowania" ${ }^{69}$. Przywołując list Jana Pawła II oraz nauczanie społeczne Kościoła abp Skworc przekonywał, że odpoczynek jest ważnym elementem życia człowieka. Opowiedział się też za obroną pracownika przed wyzyskiem i poniżeniem ze strony pracodawcy, który jest stroną silniejszą ${ }^{70}$.

63 A. Wuwer, D. Szlachta, Caritas et Iustitia in re sociali..., dz. cyt., s. 299. Por. A. Wuwer, D. Szlachta, Mater et Familiae Advocata ..., dz. cyt., s. 235.

64 W. Świątkiewicz, Profanizacja dies Domini..., art. cyt., s. 56, 58-60.

65 Jan Paweł II, List apostolski „Dies Domini” o świętowaniu niedzieli, Tarnów 1998, nr 7.

66 Materiały z sympozjum: zob. Świętowanie niedzieli..., dz. cyt.

${ }^{67}$ Więcej o tym wydarzeniu: zob. Rozmowa z ks. Arkadiuszem Wuwerem z 3 kwietnia 2014 r. przeprowadzona przez D. Szlachtę (w zbiorach autora); Rozmowa z prof. Wojciechem Świątkiewiczem z 18 sierpnia 2014 r. przeprowadzona przez D. Szlachtę (w zbiorach autora); A. Wuwer, Dorobek piekarskich sympozjów naukowych w monografiach konferencyjnych (1992-2016), ŚSHT 51 (2018), z. 1, s. 192-209 (tam też geneza sympozjów oraz wykaz publikacji sympozjalnych, autorów i ich tekstów).

68 A. Wuwer, D. Szlachta, Caritas et Iustitia in re sociali..., dz. cyt., s. 305.

69 A. Wuwer, D. Szlachta, Caritas et Iustitia in re sociali..., dz. cyt., s. 306.

70 B. Drożdż, Istota świętowania, czyli dlaczego mamy świętować?, w: Świętowanie niedzieli..., dz. cyt., s. 51-53. 
Podczas pielgrzymki mężczyzn w 2015 r. abp Wiktor Skworc stwierdził, że niedziela to „być albo nie być” dla rodziny, Kościoła i społeczeństwa. Mówił o niedzieli nie tylko kontekście religijnym. W tym celu przypomniał apel biskupów i zwierzchników Kościołów zrzeszonych w Polskiej Radzie Ekumenicznej ze stycznia 2015 r. skierowany: „także do tych, od których zależy społeczny kształt świętowania niedzieli w Polsce: apelujemy do pracowników, by w niedziele i święta nie podejmowali niekoniecznej pracy zarobkowej; apelujemy do pracodawców, by uszanowali świętość dnia Pańskiego, nie angażując zawodowo pracowników, jeżeli nie jest to bezwzględnie konieczne; apelujemy do parlamentarzystów, by zapewnili takie uregulowania prawne, które uszanują w naszej Ojczyźnie prawo ludzi pracy do niedzielnego wypoczynku i świętowania; apelujemy do władz, by uczyniły wszystko w celu ochrony niedzieli, tak aby człowiek nie był traktowany jako narzędzie zysku i mógł przeżywać niedzielę zgodnie ze swoimi przekonaniami; apelujemy wreszcie do wszystkich ludzi dobrej woli o poszanowanie niedzieli i świąt z uwagi na społeczny pożytek należnego odpoczynku i świętowania - dla dobra naszych rodzin, dla dobra obywateli naszego państwa" ${ }^{\text {"71 }}$.

Kolejnym argumentem dla arcybiskupa katowickiego za wprowadzeniem zakazu handlu w niedzielę jest fakt, że w wielu krajach sklepy w niedzielę są zamknięte. Podczas pielgrzymki mężczyzn w 2017 r. mówca wymieniał kraje, w których obowiązuje zakaz handlu niedzielnego. Wśród nich są: „Austria, Grecja, Belgia, Francja, Luksemburg, Norwegia, Holandia, Wielka Brytania. Każde z tych państw chroni w ten sposób życie rodzinne i prywatne obywateli. W Niemczech niedziela jest chroniona zapisem w konstytucji jako wartość i spoiwo wspólnoty narodowej" $"$.

Dlatego też „i my powinniśmy - jako kraj i naród - przyjąć rozwiązania regulujące rytm pracy i odpoczynku, obowiązujące w wielu nowoczesnych krajach Europy! Także nasza Konstytucja i prawa Unii Europejskiej gwarantują obronę życia rodzinnego oraz ochronę pracy. To wystarczające racje prawne na rzecz wprowadzenia ograniczenia handlu" "73.

Metropolita katowicki poparł wprowadzenie zakazu również w naszym kraju, o czym wspomniał podczas pielgrzymki kobiet w 2016 r. Wówczas pojawiła się bowiem inicjatywa ustawodawcza o ograniczeniu handlu w niedzielę. Według abp. Wiktora Skworca: „Jest to legalna droga do odzyskania niedzieli «Bożej i naszej», sprzyjającej umocnieniu, a może niekiedy odrodzeniu zagubionych więzi rodzinnych i społecznych. Dramatyzm tej sytuacji potwierdza jeszcze fakt, że to właśnie w niedzielę - najczęściej w handlu - zatrudniane są kobiety: żony i matki. Ten stan

${ }^{71}$ Apel biskupów Kościoła rzymskokatolickiego w Polsce i zwierzchników Kościołów zrzeszonych w Polskiej Radzie Ekumenicznej o poszanowaniu i chrześcijańskim świętowaniu niedzieli. Warszawa, 20 stycznia 2015 r., WA 83 (2015), nr 1, s. 24-25; A. Wuwer, D. Szlachta, Caritas et Iustitia in re sociali..., dz. cyt., s. 321-322.

${ }^{72}$ W. Skworc, Idźcie i głoście! Jest nadzieja! ..., art. cyt., s. 335.

73 W. Skworc, Idźcie i głoście! Jest nadzieja!..., art. cyt., s. 335. 
trzeba zmienić, dlatego raz jeszcze apeluję o składanie deklaracji poparcia dla inicjatywy ustawodawczej o ograniczeniu handlu w niedzielę!"74.

Abp Skworc zdawał sobie sprawę z tego, że wielu jest przeciwników zakazu w handlu niedzielę. Dla nich podczas pielgrzymki kobiet w 2019 r. przedstawił orzeczenie Federalnego Trybunału Konstytucyjnego, w którym można przeczytać: „Zasada ochrony niedzieli ma nie tylko wymiar religijny, ale również ogólnospołeczny. Pozwala na fizyczną i psychiczną regenerację osoby pracownika po tygodniu pracy, sprzyja rozbudowie więzi międzyludzkich (w tym rodzinnych), wpływa na poprawę sposobu postrzegania człowieka przez wielkie podmioty gospodarcze, które często sprowadzają go do narzędzia zysku, a także pozytywnie oddziałują na branżę handlową. W ten sposób zakaz handlu niedzielnego, nawet gdy jest stosowany z ustawowo przewidzianymi wyjątkami, sprzyja realizacji wielu zasad, praw i wolności konstytucyjnych, tj. nietykalności osobistej, zasady ochrony rodziny i małżeństwa, zasady przyrodzonej godności człowieka oraz wolności gospodarczej. W tym ostatnim przypadku chodzi o ograniczenie przewagi wielkich przedsiębiorstw, które w przeciwieństwie do małych sklepów dysponują licznymi zasobami kadrowymi, umożliwiającymi im pracę przez 7 dni w tygodniu"75.

Mimo sprzeciwów w poszczególnych latach zakaz handlu w niedzielę udało się sukcesywnie wprowadzić w życie. Rozwiązanie to poparli również obywatele, którzy uznali, że „Postulowana ustawa bierze w obronę człowieka; ponad milion osób, szczególnie kobiet, pracujących - wykonujących prace niekonieczne - w niedziele i dni świąteczne. Podkreśla też wartość niedzieli, jako dobra kulturowego i dnia wolnego od pracy [...]. Uważamy, że zarówno proponowanie zmian w projekcie ustawy, jak też przeciąganie prac legislacyjnych jest formą niesprawiedliwości społecznej, także wobec tych obywateli, którzy poparli projekt swoim podpisem"76.

Arcybiskup katowicki wskazywał, że niedziela jest także dniem człowieka. Dlatego jasno się dopominał, „by niedzielę zwrócić człowiekowi. Każdemu człowiekowi. Bo niedziela nie jest luksusem, zbytkiem dla najbogatszych i bogatych. Niedziela jest dla każdego. Jest bezcenna dla człowieka i jego rodziny, a państwo powinno ją chronić prawem jak świętość!’’77.

74 W. Skworc, Stowo Arcybiskupa Katowickiego podczas pielgrzymki stanowej kobiet i dziewcząt do Sanktuarium Matki Bożej Piekarskiej, Piekary Śląskie, 21 sierpnia 2016 roku, WA 84 (2016), nr 7, s. 563; A. Wuwer, D. Szlachta, Mater et Familiae Advocata..., dz. cyt., s. 261.

75 Hierarcha cytuje tu dokument Wolna niedziela $w$ orzecznictwie Federalnego Trybunatu Konstytucyjnego w Karlsruhe, Wnioski, pkt D.700. Zob. W. Skworc, Po moc Bożego Ducha! Stowo pasterskie Arcybiskupa Katowickiego podczas pielgrzymki stanowej dziewcząt i kobiet do Sanktuarium Matki Bożej Piekarskiej, Piekary Śląskie, 18 sierpnia 2019 roku, WA 87 (2019), nr 7-8, s. 698-699. Zob. także A. Drożdż, Rodzina zanurzona w fenomenie weekendowym, w: Świętowanie niedzieli..., dz. cyt., s. 88-90.

76 W. Skworc, Idźcie i głoście! Jest nadzieja!..., art. cyt., s. 334-335.

77 W. Skworc, Idźcie i głoście! Jest nadzieja! ..., art. cyt., s. 335. Por. A. Wuwer, D. Szlachta, Mater et Familiae Advocata ..., dz. cyt., s. 262. 
Równocześnie abp Skworc stale przywoływał hasło „niedziela Boża i nasza” i wyraził życzenie, by było aktualne w III Rzeczypospolitej. Jest to warunek wypełnienia trzeciego przykazania Bożego, którego nie wolno lekceważyć, ,jeśli chcemy się ostać jako rodziny, społeczeństwo i państwo"78.

Podczas pielgrzymki kobiet w 2017 r. arcybiskup katowicki prosił pracowników Ministerstwa Rodziny, Pracy i Polityki Społecznej o „więcej empatii wobec kobiet, których symbolem są te z nich, które w niedziele zmuszane są do obsługi kas w supermarketach [...]. Rodzina potrzebuje nie tylko pomocy finansowej-progra$\mathrm{mu} \ll 500+»$, ale także czasu dla siebie. Potrzebuje programu «Niedziela+»!!»79.

Równocześnie metropolita apelował do pątniczek, aby mimo trudności nie rezygnowały ze świątecznego charakteru niedzieli. Wzywał też do przeżywania tego dnia we wspólnocie rodzinnej i parafialnej ${ }^{80}$.

Podczas męskiej pielgrzymki w 2017 r. arcybiskup katowicki poruszył także problem migracji. Zauważył, że to nie przybysze są dla Polaków największym zagrożeniem. Według abp. Skworca jest nim „słabość Europy i Europejczyków spowodowana utratą pamięci i dziedzictwa chrześcijańskiego, co wywołuje u wielu Europejczyków, Polaków również, wrażenie, że żyją bez duchowego zaplecza niczym spadkobiercy, którzy roztrwonili dziedzictwo, majątek pozostawiony im przez przodków. A w zamian otrzymali w nadobfitości wytwory kultury materialnej, królestwo rzeczy, skutecznie odcinające sytych od życiodajnego źródła, jakim jest chrześcijaństwo" 81 .

W 2018 r. wprowadzono pierwszy etap zakazu handlu niedzielnego. Dzięki temu sklepy i galerie handlowe były zamknięte przez dwie niedziele w miesiącu. Katowicki metropolita miał przy tym na uwadze, że wielu będzie chciało ominąć ten zakaz. Dlatego zachęcił pielgrzymów, aby nie ulegli ich propagandzie. Zdaniem arcybiskupa „Polska nie może pozwalać na to, aby lekceważono państwo prawa. Setki tysięcy zatrudnionych, zwłaszcza kobiet, nie muszą w niedzielę pracować - mogą odpocząć i być dla rodziny. Zauważamy, jak w dwie wolne od handlu niedziele zmienia się styl życia, uczymy się na nowo świętować i być dla siebie. Przeżywanie tego jest treścią hasła Metropolitalnego Święta Rodziny: «Rodzina - radość miłości!»»82.

78 W. Skworc, Idźcie i głoście! Jest nadzieja! ..., art. cyt., s. 335.

79 W. Skworc, Idźcie i głoście! Stowo Arcybiskupa Katowickiego podczas pielgrzymki stanowej kobiet do Sanktuarium Matki Bożej Piekarskiej 20 sierpnia 2017 roku, WA 85 (2017), nr 7-8, s. 454.

80 W. Skworc, Idźcie i głoście! Stowo..., art. cyt., s. 454; W. Skworc, Jesteśmy napetnieni Duchem Świętym! Stowo Arcybiskupa Katowickiego podczas pielgrzymki stanowej dziewcząt i kobiet do Sanktuarium Matki Bożej Piekarskiej 19 sierpnia 2018 roku, WA 86 (2018), nr 7-8, s. 512.

81 W. Skworc, Idźcie i głoście! Jest nadzieja!..., art. cyt., s. 335.

82 W. Skworc, Jesteśmy napetnieni Duchem Świętym! Słowo Arcybiskupa Katowickiego podczas pielgrzymki stanowej mężczyzn i młodzieńców do Sanktuarium Matki Bożej Piekarskiej, Piekary Śląskie, 27 maja 2018 roku, Uroczystość Najświętszej Trójcy, WA 86 
W 2019 r. wprowadzono kolejny etap zakazu handlu w niedzielę. Od tego momentu sklepy i galerie mogły być otwarte tylko w ostatnią niedzielę miesiąca. Mimo to arcybiskup przypominał: „Pamięć o Bogu to pamięć o Jego przykazaniach! Pamiętaj, abyś dzień święty święcił (III)! Tu, u Matki Bożej Piekarskiej, stoimy od zawsze na straży niedzieli, bo «niedziela jest Boża i nasza»! Wszyscy uczmy się rodzinnego świętowania, przeżywania niedzieli. W tym dniu trzeba «pamiętać o Panu, Bogu twoim, bo On udziela ci siły do zdobycia bogactwa»; trzeba umacniać więzi z najbliższymi, którzy na różne sposoby zbyt szybko odchodzą; trzeba wyrywać się z kieratu codzienności ku światłu Bożej prawdy i miłości. Trzeba zbliżyć się do natury i kultury! A przy tym, Bracia, nie rezygnujcie, proszę, z niedzielnej Mszy Świętej, z sakramentu pokuty, z uczynków miłosierdzia, z odwiedzania starszych i chorych krewnych, znajomych. Umacniajcie się dobrym słowem, także tym drukowanym w naszym tygodniku dobrych wiadomości, jakim jest «Gość Niedzielny»"

Od 2020 r. jedynie kilka niedziel w roku ma charakter handlowy. Według abp. Wiktora Skworca jest to sprzeciw wobec próby „uczynienia z pieniądza zastępczego bożka, która konsumpcję każe traktować jako zastępczą religię. Do tego chce nas zmusić dyktat ekonomii i koncernów, które walczą z niedzielą, aby ludzie w ich świątyniach - supermarketach - odprawiali niedzielne nabożeństwa zakupów i konsumpcji, aż po utratę wolności przez zadłużenie" ${ }^{84}$.

Wskutek epidemii koronowirusa, która opanowała cały świat, ciągle szuka się okazji do obejścia zakazu handlu niedzielnego. Wzbudziło to niepokój arcybiskupa katowickiego, który w 2020 r. mówił: „Na stronach dziennika lansującego się jako organ opiniotwórczy regularnie pojawiają się teksty o tym, jakoby Polacy mieli dość zakazu handlu w niedziele. Na potwierdzenie tej tezy przytacza się wyłącznie argumenty natury ekonomicznej: że «zyska gospodarka, zyskają sklepy, zakupy będą łatwiejsze, a nawet tłok będzie mniejszy». Trzeba postawić pytanie, gdzie w tych badaniach - często przygotowywanych «na zamówienie» - jest człowiek? Gdzie są pracownicy handlu, kobiety, żony i matki? Gdzie jest rodzina, poszanowanie odpoczynku i prawa do duchowego rozwoju człowieka, prawa do spotkania z naturą i kulturą?" 85 .

Arcybiskup zatem apelował do zgromadzonych pielgrzymów: „Bracia, nie możemy się zgodzić na dyktaturę różnych organizacji, korporacji zajmujących się handlem i dystrybucją towarów, które nie biorą pod uwagę kosztów społecz-

(2018), nr 5, s. 363-364.

83 W. Skworc, W mocy Bożego Ducha! Nauczanie społeczne Arcybiskupa Katowickiego, WA 87 (2019), nr 5, s. 475.

${ }^{84}$ W. Skworc, Po moc Bożego Ducha!..., art. cyt., s. 698-699.

${ }^{85}$ Pomóż nam wygrać, Lekarko, nasz czas. Stowo arcybiskupa Wiktora Skworca podczas pielgrzymki, WA 88 (2020), nr 5, s. 296. 
nych, jakie płyną z niszczenia narodowej tkanki społecznej poprzez pozbawiania jej tego spoiwa, jakim jest wspólne przeżywanie czasu wolnego i świętowanie niedzieli przez rodziny i całe społeczeństwo. To element naszej kulturowej tożsamości. Nie możemy się godzić na jego niszczenie. Szanujmy niedzielę jako święty dzień chrześcijaństwa i kultury europejskiej jak inne europejskie kraje (np. Niemcy)" "86.

Podczas tego samego przemówienia metropolita zapowiedział, że zawsze będzie trwała obrona niedzieli jako dnia Boga i człowieka oraz praw pracowniczych naruszanych z powodu niekoniecznej pracy w niedzielę ${ }^{87}$.

\section{Zakończenie}

Podczas pielgrzymek stanowych do sanktuarium Matki Bożej Piekarskiej zawsze toczyła się walka o wolność i godność człowieka. Ważną rolę odgrywają w tym przesłania wygłaszane przez biskupów katowickich do pielgrzymów zebranych na Wzgórzu Piekarskim.

Jednym z przejawów tej walki jest także obrona sakralnego charakteru niedzieli, która jest „Boża i nasza”. Inaczej walka ta wyglądała w okresie PRL, kiedy to ówczesna władza chciała zawłaszczyć niedziele poprzez zmuszanie ludzi do pracy. Przejawem tego był wprowadzony w 1977 r. czterobrygadowy system pracy w górnictwie oraz tzw. czyny społeczne. Praktykom tym sprzeciwiał się stanowczo bp Herbert Bednorz, który bronił niedzieli jako dnia dla człowieka, rodziny i wypoczynku.

Po odzyskaniu wolności zagrożeniem dla sakralnego charakteru niedzieli stał się rozwój niedzielnego handlu, powstanie centrów handlowych. Był to rezultat wejścia w życie mechanizmów gospodarki rynkowej oraz konsumpcyjnego stylu życia prowadzącego do laicyzacji i zniewolenia człowieka stającego się tylko trybikiem w maszynie rynkowej. Stanowiło to przedmiot troski o świąteczny charakter niedzieli następców bp. Bednorza, którymi byli: abp Damian Zimoń i pełniący te obowiązki do dzisiaj abp Wiktor Skworc.

Dlatego też zagadnienia związane z zachowaniem sakralnego charakteru niedzieli są często poruszane przez biskupów katowickich przy różnych okazjach, zwłaszcza w czasie stanowych pielgrzymek do sanktuarium Matki Bożej w Piekarach Śląskich. W ostatnich latach temat ten często pojawia się w wypowiedziach abp. Wiktora Skworca, który w ten sposób sprzeciwia się otwieraniu w ten dzień galerii handlowych.

${ }^{86}$ Pomóż nam wygrać..., art. cyt., s. 296.
${ }^{87}$ Pomóż nam wygrać..., art. cyt., s. 296. 


\section{Bibliografia}

\section{Źródła drukowane}

Apel biskupów Kościoła rzymskokatolickiego w Polsce i zwierzchników Kościołów zrzeszonych w Polskiej Radzie Ekumenicznej o poszanowaniu i chrześcijańskim świętowaniu niedzieli. Warszawa, 20 stycznia 2015 r., „Wiadomości Archidiecezjalne. Organ Urzędowy Kurii Metropolitalnej w Katowicach” 83 (2015), nr 1, s. 24-25.

Ciagle tonę i chwytam Jezusa. Z abp. Damianem Zimoniem rozmawiaja Alina Petrowa-Wasilewicz i ks. Jerzy Szymik, Katowice 2002.

Jan Paweł II, List apostolski „Dies Domini” o świętowaniu niedzieli, Tarnów 1998.

Katechizm Kościoła Katolickiego, wyd. 2, Poznań 2002.

Kodeks prawa kanonicznego, Poznań 1984.

Kościót Robotników. Kronika kościoła pw. Najświętszej Marii Panny Matki Kościoła w Jastrzębiu-Zdroju 1974-1988, Jastrzębie-Zdrój 2014.

Pięć przykazań kościelnych, „Wiadomości Archidiecezjalne. Organ Urzędowy Kurii Metropolitalnej w Katowicach" 82 (2014), nr 4, s. 140-142.

Pomóż nam wygrać, Lekarko, nasz czas. Stowo arcybiskupa Wiktora Skworca podczas pielgrzymki, „Wiadomości Archidiecezjalne. Organ Urzędowy Kurii Metropolitalnej w Katowicach" 88 (2020) nr 5, s. 291-298.

Skworc W., Idźcie i głoście! Jest nadzieja! Stowo Arcybiskupa Katowickiego podczas pielgrzymki stanowej mężczyzn i młodzieńców do Sanktuarium Matki Bożej Piekarskiej 28 maja 2017 roku, „Wiadomości Archidiecezjalne. Organ Urzędowy Kurii Metropolitalnej w Katowicach" 85 (2017), nr 5, s. 333-339.

Skworc W., Idźcie i głoście! Stowo Arcybiskupa Katowickiego podczas pielgrzymki stanowej kobiet do Sanktuarium Matki Bożej Piekarskiej 20 sierpnia 2017 roku, „Wiadomości Archidiecezjalne. Organ Urzędowy Kurii Metropolitalnej w Katowicach" 85 (2017), nr 7-8, s. 450-456.

Skworc W., Jesteśmy napetnieni Duchem Świętym! Stowo Arcybiskupa Katowickiego podczas pielgrzymki stanowej dziewczat i kobiet do Sanktuarium Matki Bożej Piekarskiej 19 sierpnia 2018 roku, „Wiadomości Archidiecezjalne. Organ Urzędowy Kurii Metropolitalnej w Katowicach" 86 (2018), nr 7-8, s. 507-514.

Skworc W., Jesteśmy napetnieni Duchem Świętym! Stowo Arcybiskupa Katowickiego podczas pielgrzymki stanowej mężczyzn i młodzieńców do Sanktuarium Matki Bożej Piekarskiej, Piekary Ślaskie, 27 maja 2018 roku, Uroczystość Najświętszej Trójcy, „Wiadomości Archidiecezjalne. Organ Urzędowy Kurii Metropolitalnej w Katowicach" 86 (2018), nr 5, s. 358-365. 
Skworc W., Ojcowskim sercem. Stowo społeczne Metropolity Katowickiego, „Wiadomości Archidiecezjalne. Organ Urzędowy Kurii Metropolitalnej w Katowicach" 89 (2021), nr 5, s. 344-354.

Skworc W., Po moc Bożego Ducha! Stowo pasterskie Arcybiskupa Katowickiego podczas pielgrzymki stanowej dziewcząt i kobiet do Sanktuarium Matki Bożej Piekarskiej, Piekary Śląskie, 18 sierpnia 2019 roku, „Wiadomości Archidiecezjalne. Organ Urzędowy Kurii Metropolitalnej w Katowicach" 87 (2019), nr 7-8, s. 693-702.

Skworc W., Stowo Arcybiskupa Katowickiego podczas pielgrzymki stanowej kobiet i dziewcząt do Sanktuarium Matki Bożej Piekarskiej, Piekary Ślaskie, 21 sierpnia 2016 roku, „Wiadomości Archidiecezjalne. Organ Urzędowy Kurii Metropolitalnej w Katowicach" 84 (2016), nr 7, s. 559-565.

Skworc W., W mocy Bożego Ducha! Nauczanie społeczne Arcybiskupa Katowickiego, „Wiadomości Archidiecezjalne. Organ Urzędowy Kurii Metropolitalnej w Katowicach" 87 (2019), nr 5, s. 468-476.

Sobór Watykański II. Konstytucje, dekrety, deklaracje. Tekst łacińsko-polski, wyd. 2, Poznań 2008.

Zimoń D., Stowo pasterskie biskupa katowickiego w zwiazku ze strajkami, „Wiadomości Diecezjalne. Organ Urzędowy Kurii Diecezjalnej w Katowicach" 56 (1988), nr 8, s. 264-265.

\section{Relacje ustne}

Biskup robotników. Przemówienia bp. Bednorza w Piekarach Ślaskich, dodatek CD do „Gościa Niedzielnego” przygotowany na pielgrzymkę mężczyzn i młodzieńców w 2008 r.

Rozmowa z abp. Damianem Zimoniem z 13 grudnia 2013 r. przeprowadzona przez D. Szlachtę (w zbiorach autora).

Rozmowa z abp. Wiktorem Skworcem z 3 kwietnia 2014 r. przeprowadzona przez D. Szlachtę (w zbiorach autora).

Rozmowa z ks. Arkadiuszem Wuwerem z 3 kwietnia 2014 r. przeprowadzona przez D. Szlachtę (w zbiorach autora).

Rozmowa z prof. Wojciechem Świątkiewiczem z 18 sierpnia 2014 r. przeprowadzona przez D. Szlachtę (w zbiorach autora).

\section{Opracowania}

Basiuk M., Biblijne i patrystyczne korzenie świętowania dnia Pańskiego, w: Świętowanie niedzieli $w$ wymiarze społeczno-etycznym. XXII Społeczne Sympozjum Piekarskie, red. A. Wuwer, Katowice 2013, s. 135-142. 
Drożdż A., Rodzina zanurzona $w$ fenomenie weekendowym, w: Świętowanie niedzieli w wymiarze społeczno-etycznym. XXII Społeczne Sympozjum Piekarskie, red. A. Wuwer, Katowice 2013, s. 85-95.

Drożdż B., Istota świętowania, czyli dlaczego mamy świętować?, w: Świętowanie niedzieli $w$ wymiarze społeczno-etycznym. XXII Społeczne Sympozjum Piekarskie, red. A. Wuwer, Katowice 2013, s. 47-54.

Dziurok A., Mowa do ludu, w: Życie w komunistycznym kraju. Polacy w latach 1944-1989, cz. 6, Robotnicy przeciwko wtadzy, dodatek do „Gościa Niedzielnego" przygotowany we współpracy z Instytutem Pamięci Narodowej, 12 VI 2011 r., s. 13.

Górecki J., Pielgrzymki do Piekar Ślaskich w latach 1946-1947 w świetle okólników Kurii Diecezjalnej w Katowicach, „Peregrinus Cracoviensis” 26 (2015), nr 1, s. 21-34.

Grajewski A., Biskup katowicki Herbert Bednorz wobec władzy komunistycznej na Górnym Ślasku w latach 1967-1985. Zarys problematyki, w: Biskup Herbert Bednorz - zycie i postuga czwartego biskupa katowickiego. W setna rocznice urodzin biskupa Herberta Bednorza, red. I. Celary, Katowice-Piekary Śląskie 2008, s. 31-42.

Hoinkis A., Teologia świętowania niedzieli jako dnia Pańskiego, w: Świętowanie niedzieli $w$ wymiarze społeczno-etycznym. XXII Społeczne Sympozjum Piekarskie, red. A. Wuwer, Katowice 2013, s. 169-178.

Kłakus M., Kościót i robotnicy. Kościót katolicki na Górnym Śląsku wobec Pierwszej Solidarności w Jastrzębiu-Zdroju, Katowice 2011.

Kołek A., Problematyka społeczno-religijna w kaznodziejstwie biskupa Herberta Bednorza (1967-1989), Katowice 2002.

Kurpierz T., Neja J., „Solidarność” śląsko-dąbrowska 1980-1981. Szkic do monografii i dokumenty wtasne, Katowice 2012.

Łuczak M., Teologia społeczna w Kościele katowickim 1925-2010, Częstochowa 2013.

Marek Ł., Obrzędowość świecka, w: Przez Morze Czerwone. Kościół w Polsce pod rzadami komunistów, cz. 5, Życie codzienne katolika w PRL. Dodatek do tygodnika „Gość Niedzielny” z 14 IX 2008 r., s. 6-7.

Misiak R., Świętowanie Dnia Pańskiego w perspektywie tożsamości, w: Świętowanie niedzieli $w$ wymiarze społeczno-etycznym. XXII Społeczne Sympozjum Piekarskie, red. A. Wuwer, Katowice 2013, s. 96-113.

Mówię do Was: Szczęść Boże! Kardynat Karol Wojtyła - Ojciec Święty Jan Pawet II w Piekarach Ślaskich, komentarze oprac. J. Kiedos, S. Cichy, E. Nalepa, zebrali B. Pietyra, J. Przybyła, B. Woźnica, wyd. 2, Katowice 2005.

Myszor J., Historia diecezji katowickiej, Katowice 1999.

Neja J., Dwa strajki - dwa porozumienia, „Biuletyn IPN. Pismo o najnowszej historii Polski” 9-10 (2010), nr 118-119, s. 65-74. 
Neja J., Matecznik komunistów czy region buntu?, „Biuletyn IPN. Pismo o najnowszej historii Polski” 9 (2017), nr 142, s. 96-111.

Neja J., Pierwsi w kraju. Komitet Wolnych Związów Zawodowych w Katowicach, „Biuletyn IPN. Pismo o najnowszej historii Polski” 4 (2018), nr 149, s. 17-31.

Olszar H., Iustitia socialis Kościoła katowickiego w czasach zniewolenia i wolności, w: Sprawiedliwość i mitość społeczna. Refleksja interdyscyplinarna w 90-lecie (archi)diecezji katowickiej, red. A. Wuwer, Katowice 2015, s. 51-63.

Olszar H., „Niedziela Boża i nasza”. Walka biskupa Herberta Bednorza z władza ludowa o Dzień Pański wolny od pracy, w: Świętowanie niedzieli w wymiarze społeczno-etycznym. XXII Społeczne Sympozjum Piekarskie, red. A. Wuwer, Katowice 2013, s. 36-43.

Olszowski G., Herbert Bednorz - organizator i kierownik referatu duszpasterskiego Kurii Diecezjalnej w Katowicach, w: Biskup Herbert Bednorz - życie i postuga czwartego biskupa katowickiego. W setna rocznice urodzin biskupa Herberta Bednorza, red. I. Celary, Katowice-Piekary Śląskie 2008, s. 77-94.

Suchoń A., Stan etosu pracy górnika śląskiego w okresie rząów totalitarnych, „Śląskie Studia Historyczno-Teologiczne" 25/26 (1992/1993), s. 99-119.

Surmiak W., ,W niedzielę oraz święta nakazane uczestniczyć we mszy świętej i powstrzymać się od prac niekoniecznych" - prawno-moralny sens pierwszego przykazania kościelnego, w: Świętowanie niedzieli w wymiarze społeczno-etycznym. XXII Społeczne Sympozjum Piekarskie, red. A. Wuwer, Katowice 2013, s. 143-159.

Szlachta D., Arcybiskup Damian Zimoń - ,, biskup bezrobotnych”, „Śląskie Studia Historyczno-Teologiczne" 53 (2020), z. 1, s. 74-95.

Szlachta D., Bednorz Herbert, w: Leksykon Panteonu Górnośląskiego, red. A. Kłos-Skrzypczak, H. Olszar, Katowice 2020, s. 53-61.

Szlachta D., Herbert Bednorz (1908-1989), , biskup robotników”, w: Logos i ethos w polityce. Księga jubileuszowa Profesora Stanisława Wójcika, red. A. Łukasik-Turecka, K. Słowiński, Lublin 2020, s. 77-97.

Szlachta D., Ksiadz Bernard Czernecki - kapelan Solidarności w Jastrzębiu i duszpasterz ludzi pracy, „Biuletyn IPN. Pismo o najnowszej historii Polski” 7-8 (2021), nr 188-189, s. 64-75.

Szlachta D., Pielgrzymki stanowe do sanktuarium w Piekarach Ślaskich w latach 1945-2020, „Studia Sandomierskie” 27 (2020), s. 139-169.

Szlachta D., Tematy spoteczne poruszane przez biskupów katowickich podczas pielgrzymek stanowych do Piekar Ślaskich, w: Wolność człowieka i jej granice, red. K. Kozioł, Lublin 2017, s. 70-89.

Świątkiewicz W., Profanizacja dies Domini. Między przyzwoleniem a zgorszeniem, w: Świętowanie niedzieli w wymiarze spoleczno-etycznym. XXII Społeczne Sympozjum Piekarskie, red. A. Wuwer, Katowice 2013, s. 55-70.

Til P., Biskupi polscy o świętowaniu niedzieli, Katowice 2017. 
Tracz B., Cios sierp(ni)owy. Strajki na Górnym Śląsku w 1988 r., „Biuletyn IPN. Pismo o najnowszej historii Polski” 4 (2019), nr 161, s. 13-24.

Tracz B., Niezrealizowane postulaty. Strajkowe lato 1988 roku w województwie katowickim, „Biuletyn IPN. Pismo o najnowszej historii Polski” 9 (2017), nr 142, s. $112-126$.

Wiara, modlitwa i życie w Kościele katowickim, red. B. Woźnica, I. Mierzwa, M. Połomska, R. Rak, S. Szymecki, wyd. 2, Katowice 2012.

Woźnica B., Ks. bp Herbert Bednorz w obronie społecznych interesów świata pracy, „Śląskie Studia Historyczno-Teologiczne” 22 (1989), s. 37-40.

Wójcik B., TKKŚ - pomocnik PZPR, „Biuletyn IPN. Pismo o najnowszej historii Polski" 7-8 (2021), nr 188-189, s. 134-145.

Wuwer A., Dorobek piekarskich sympozjów naukowych w monografiach konferencyjnych (1992-2010), „Śląskie Studia Historyczno-Teologiczne” 51 (2018), z. 1, s. 192-209.

Wuwer A., Etyczno-spoleczna interpretacja maryjnego tytulu „, Matka sprawiedliwości i miłości społecznej”, w: Sprawiedliwość i miłość społeczna. Refleksja interdyscyplinarna w 90-lecie (archi)diecezji katowickiej, red. A. Wuwer, Katowice 2015, s. 13-30.

Wuwer A., Nauczanie społeczne arcybiskupa metropolity Damiana Zimonia podczas stanowych pielgrzymek mężczyzn i młodzieńców do Piekar Śląskich w latach 1986-2004, w: Rocznice, które wspominaja, uobecniaja i zapowiadaja. Zagadnienia teologiczne, socjologiczne i historyczne, red. J. Kozyra, M. Łuczak, Katowice-Piekary Śląskie 2005, s. 33-76.

Wuwer A., Szlachta D., Caritas et Iustitia in re sociali. Przestanie społeczne biskupów katowickich podczas stanowych pielgrzymek mężczyzn do Piekar Śląskich (1966-2016). Edycja źródet z komentarzem, Katowice 2017.

Wuwer A., Szlachta D., De profundis ad Te clamamus. Świat górników w radiowych i telewizyjnych homiliach biskupów katowickich (1983-2016). Edycja źródet z komentarzem, Katowice 2017.

Wuwer A., Szlachta D., Mater et Familiae Advocata. Przesłanie społeczne biskupów katowickich podczas stanowych pielgrzymek kobiet i panien do Piekar Ślaskich (1966-2016). Edycja źródet z komentarzem, Katowice 2017.

Zimoń D., Droga Kościoła jest człowiek. Kościót katowicki wobec problemów spotecznych w latach 1985-1995, Katowice 1995.

Zimoń D., Pochylmy się nad bezrobociem, Katowice 2002.

Zimoń D., „Przywracajmy nadzieję ubogim” - oto zadanie dla Kościoła na Ślasku, w: Z tej ziemi. Ślaski kalendarz katolicki na rok 2006, Katowice 2005, s. 29-32. 


\section{Streszczenie}

Ważnym zagadnieniem wymagającym omówienia jest wątek świętowania niedzieli jako dnia Pańskiego. Wbrew pozorom temat ten nie stracił na aktualności, dlatego też podjęto próbę opracowania uwzględniającą nauczanie biskupów podczas pielgrzymek do Piekar Śląskich. Należą do nich pielgrzymki stanowe mężczyzn i młodzieńców odbywające się w ostatnią niedzielę maja oraz pielgrzymki kobiet i panien organizowane w niedzielę po 15 sierpnia. Temat sakralnego charakteru niedzieli poruszali kolejni biskupi katowiccy: Herbert Bednorz, Damian Zimoń i Wiktor Skworc. W okresie PRL przymus pracy w niedzielę był skutkiem wieloletniego rozwoju przemysłu na Górnym Śląsku oraz działań ówczesnych władz, które dążyły do zniewolenia człowieka. Miał temu służyć czterobrygadowy system pracy w kopalniach, który wprowadzono oficjalnie w $1977 \mathrm{r}$. W odpowiedzi powstało słynne hasło pielgrzymkowe: ,niedziela Boża i nasza”. Po przemianach 1989 r. abp Damian Zimoń i abp Wiktor Skworc nadal przypominali to hasło, sprzeciwiając się praktyce handlu niedzielnego oraz powstawania nowych centrów handlowych. Często przemawiali w imieniu osób zatrudnionych w handlu, które nie miały czasu dla rodziny i na odpoczynek oraz nie mogły uczestniczyć w niedzielnej Mszy Świętej. Mimo wejścia w życie zakazu handlu niedzielnego zagadnienie to nadal jest aktualne, wielu bowiem szuka sposobów jego obejścia.

Słowa klucze: nauka społeczna Kościoła, pielgrzymki, antropologia, dzień Pański

\section{Katowice Bishops on the Celebration of Sunday During State Pilgrimages to Piekary Śląskie After World War II}

\section{Summary}

A particularly important issue that needs to be presented is the topic of celebrating Sunday as the Lord's Day. Contrary to appearances, this topic is still relevant, therefore an attempt has been made to include teaching from the pilgrimages to Piekary Śląskie. This term should be understood as the state pilgrimages of adult and young men which takes place on the last Sunday of May and the pilgrimages of women and girls that takes place on the Sunday after August 15. The subject of the sacred character of Sunday was discussed by the subsequent bishops of Katowice Herbert Bednorz, Damian Zimoń and Victor Skworc. This was the result of many years of industrial development in this area and the actions of the authorities during the People's Republic of Poland, which aimed at enslaving people. As was evidenced by the implementation of the four-tiered system of work in the mines, which was officially introduced in 1977. Therefore, during the pilgrimages, the famous slogan „God's Sunday and Ours" was created. After the transformations of 1989, the archbishops Damian Zimoń and Victor Skworc continued to recall this slogan, opposing the practice of conducting business on Sunday and the creation of new shopping centers. 
Therefore, they often spoke on behalf of those employed in commerce who did not have time for their family and rest, and were prevented from participating in the Sunday Mass. Despite the enforcement of the Sunday trading ban, this issue is still relevant, as many are looking for ways to circumvent it.

Key words: social teaching of the Church, pilgrimages, human rights, the Lord's Day 